\title{
Tick-borne zoonoses and commonly used diagnostic methods in human and veterinary medicine
}

\author{
Andrea Springer $^{1} \cdot$ Antje Glass $^{1} \cdot$ Julia Probst $^{1} \cdot$ Christina Strube $^{1}$ (i) \\ Received: 30 October 2020 / Accepted: 21 December 2020 / Published online: 18 January 2021 \\ (C) The Author(s) 2021
}

\begin{abstract}
Around the world, human health and animal health are closely linked in terms of the One Health concept by ticks acting as vectors for zoonotic pathogens. Animals do not only maintain tick cycles but can either be clinically affected by the same tick-borne pathogens as humans and/or play a role as reservoirs or sentinel pathogen hosts. However, the relevance of different tick-borne diseases (TBDs) may vary in human vs. veterinary medicine, which is consequently reflected by the availability of human vs. veterinary diagnostic tests. Yet, as TBDs gain importance in both fields and rare zoonotic pathogens, such as Babesia spp., are increasingly identified as causes of human disease, a One Health approach regarding development of new diagnostic tools may lead to synergistic benefits. This review gives an overview on zoonotic protozoan, bacterial and viral tick-borne pathogens worldwide, discusses commonly used diagnostic techniques for TBDs, and compares commercial availability of diagnostic tests for humans vs. domestic animals, using Germany as an example, with the aim of highlighting existing gaps and opportunities for collaboration in a One Health framework.
\end{abstract}

Keywords One Health $\cdot$ Zoonoses $\cdot$ Metazoonoses $\cdot$ Ticks $\cdot$ Tick-borne diseases $\cdot$ Lyme borreliosis $\cdot$ Diagnostics $\cdot$ Serology $\mathrm{PCR} \cdot \mathrm{ELISPOT}$

\section{Tick-borne diseases in the One Health perspective}

Ticks represent a major threat for human and animal health worldwide due to their vector function for a variety of zoonotic protozoan, bacterial and viral pathogens. These pathogens often circulate unnoticed in nature in enzootic tick-vertebrate cycles but may cause significant morbidity and mortality when spilling over to humans or domestic animals (Jahfari and Sprong 2016). For example, Anaplasma phagocytophilum mainly circulates between ticks and wildlife, but certain strains may cause granulocytic anaplasmosis in humans, dogs and horses as well as so-called tick-borne fever in domestic ruminants (Jaarsma et al. 2019). Similarly, small wild mammals constitute the main reservoir for tick-

Section Editor: Domenico Otranto

Christina Strube

christina.strube@tiho-hannover.de

1 Institute for Parasitology, Centre for Infection Medicine, University of Veterinary Medicine Hannover, Buenteweg 17,

30559 Hanover, Germany borne encephalitis virus (TBEV), which may cause neurologic disease in humans, as well as dogs and horses (Pfeffer and Dobler 2011). Additionally, domestic animals may represent an infection reservoir for tick-borne diseases (TBDs) in humans, such as cattle for Babesia divergens (Zintl et al. 2003) and dogs for Ehrlichia canis (Rar and Golovljova 2011).

Many tick species transmit zoonotic pathogens; however, some are exceptional due to their vector function for a number of different zoonotic pathogens. Thus, both the tick species infesting different hosts at the wildlife-domestic animal-human interface and the pathogens transmitted by them are of significant One Health importance. Among the particularly important tick vectors are Ixodes ricinus, Ixodes persulcatus and Ixodes scapularis, which belong to the so-called Ixodes ricinus complex, a group of 14 Ixodes species with almost worldwide distribution (Keirans et al. 1999; Xu et al. 2003). Ticks of the I. ricinus complex are confirmed vectors of zoonotic protozoa (Babesia spp.), a number of bacteria (e.g. Borrelia spp. and Rickettsiales) as well as three different flaviviruses (TBEV, Louping ill and Powassan virus). Furthermore, Dermacentor andersoni, Dermacentor variabilis and Amblyomma americanum are of particular 
One Health significance in North America (Sonenshine 2018) due to their vector function for a number of zoonotic bacterial (e.g. Rickettsia spp. and Ehrlichia spp.) and viral (e.g. Powassan and Heartland virus) pathogens.

While most zoonotic TBDs are transmitted by hard ticks, soft ticks may also play a role as vectors (Dantas-Torres et al. 2012). Several Ornithodoros spp. may transmit relapsing fever borreliae (Talagrand-Reboul et al. 2018), and this tick genus might be implicated in the transmission of Coxiella burnetii (Duron et al. 2015) and Alkhurma fever virus (Sawatsky et al. 2014).

\section{Tick-borne zoonotic protozoans}

Among tick-borne pathogens, Babesia spp. constitute the only zoonotic protozoans (Table 1), which are transmitted to humans by Ixodes ricinus (Fig. 1) and Ixodes scapularis and are thus restricted to the range of these tick species in Eurasia, Northern Africa and North America. Babesia spp. are usually highly host-specific and the natural vertebrate hosts for Babesia divergens, Babesia venatorum and Babesia microti are cattle, wild ungulates and rodents, respectively, whereas humans are mainly affected if immunocompromised (Gray et al. 2010). Interestingly, although Babesia microti occurs in both Europe and North America, symptomatic human infections have so far only been acquired in North America (Azagi et al. 2020).

\section{Tick-borne zoonotic bacteria}

In contrast to protozoans, a wide variety of zoonotic bacterial pathogens are tick transmitted (Table 2). Some of these are of major importance due to their wide geographic distribution and/ or the severity of the disease caused in humans and/or animals.
For example, Borrelia burgdorferi sensu lato (s.1.), the causative agent of Lyme borreliosis, and A. phagocytophilum occur throughout the Northern Hemisphere as both are transmitted by ticks of the Ixodes ricinus complex. Furthermore, spotted fever group rickettsiae comprise a large group of species associated with zoonotic human disease or of unknown pathogenicity, which are transmitted by different species (Fig. 2) of several hard tick genera around the world (Parola et al. 2013). Some rickettsioses are associated with high case fatality rates in humans, especially Rocky Mountain spotted fever caused by Rickettsia rickettsii and transmitted mainly by $D$. andersoni, D. variabilis (Fig. 2a) and Rhipicephalus sanguineus s.l. (Fig. 2b), and Mediterranean spotted fever caused by Rickettsia conorii and transmitted mainly by $R$. sanguineus s.l. (Parola et al. 2013).

In addition, ticks may play a role in the transmission of severe diseases such as tularemia, caused by Francisella tularensis, and so-called Q fever due to C. burnetii infection. Although other transmission routes are regarded as epidemiologically more important, several hard tick species, including D. andersoni in North America and I. ricinus (Fig. 1) as well as Dermacentor marginatus (Fig. 3a) in Eurasia, have been identified as competent vectors for both of these pathogens (Telford III and Goethert 2020; Duron et al. 2015).

\section{Tick-borne zoonotic viruses}

Compared to bacteria, none of the tick-borne viruses are distributed worldwide (the same applies to protozoans, cf. Table 1), but rather often restricted to particular geographic regions (Table 3). However, many of them cause lifethreatening disease in humans. Among tick-borne viruses, the highly pathogenic Crimean-Congo haemorrhagic fever virus (CCHFV), transmitted mainly by Hyalomma spp. (Fig.

Table 1 Tick-borne protozoan pathogens, their vectors and reservoir hosts

\begin{tabular}{|c|c|c|c|c|c|c|}
\hline Pathogen & Tick vector(s) ${ }^{1}$ & $\begin{array}{l}\text { Geographical } \\
\text { distribution }\end{array}$ & $\begin{array}{l}\text { Vertebrate } \\
\text { reservoir(s) }\end{array}$ & $\begin{array}{l}\text { Cell tropism in the } \\
\text { vertebrate host }\end{array}$ & Comment(s) & References \\
\hline $\begin{array}{l}\text { Babesia } \\
\quad \text { divergens }\end{array}$ & Ixodes ricinus & $\begin{array}{l}\text { Europe, North } \\
\text { Africa, Russia }\end{array}$ & Cattle & $\begin{array}{l}\text { Intracellular: } \\
\text { erythrocytes }\end{array}$ & & $\begin{array}{l}\text { Reviewed by Zintl } \\
\text { et al. } \\
\text { (2003) and } \\
\text { Gray } \\
\text { et al. (2019b) }\end{array}$ \\
\hline $\begin{array}{l}\text { Babesia } \\
\text { microti }\end{array}$ & $\begin{array}{l}\text { I. ricinus, Ixodes } \\
\text { scapularis }\end{array}$ & $\begin{array}{c}\text { Eurasia, North } \\
\text { America }\end{array}$ & Rodents & $\begin{array}{l}\text { Intracellular: } \\
\text { erythrocytes }\end{array}$ & $\begin{array}{l}\text { So far, only North } \\
\text { American strains } \\
\text { involved in } \\
\text { human cases }\end{array}$ & $\begin{array}{l}\text { Reviewed by Gray } \\
\text { et al. } \\
\text { (2019b); Azagi } \\
\text { et al. (2020) }\end{array}$ \\
\hline $\begin{array}{l}\text { Babesia } \\
\quad \text { venatorum }\end{array}$ & I. ricinus & Europe & $\begin{array}{l}\text { Roe deer, } \\
\text { possibly sheep }\end{array}$ & $\begin{array}{l}\text { Intracellular: } \\
\text { erythrocytes }\end{array}$ & & $\begin{array}{l}\text { Reviewed by Gray } \\
\text { et al. (2019b); } \\
\text { Gray et al. } \\
\text { (2019a) }\end{array}$ \\
\hline
\end{tabular}

\footnotetext{
${ }^{1}$ Main tick vectors responsible for human infections; other tick vectors may be relevant in tick-reservoir cycles
} 
Fig. 1 Ixodes ricinus, confirmed vector of Babesia divergens, Babesia microti and Babesia venatorum, among numerous other pathogens (left: female, right: male). Photographs were taken under an OPTIKA SLX-2 stereomicroscope (OPTIKA S.r.l., Ponteranica, Italy)

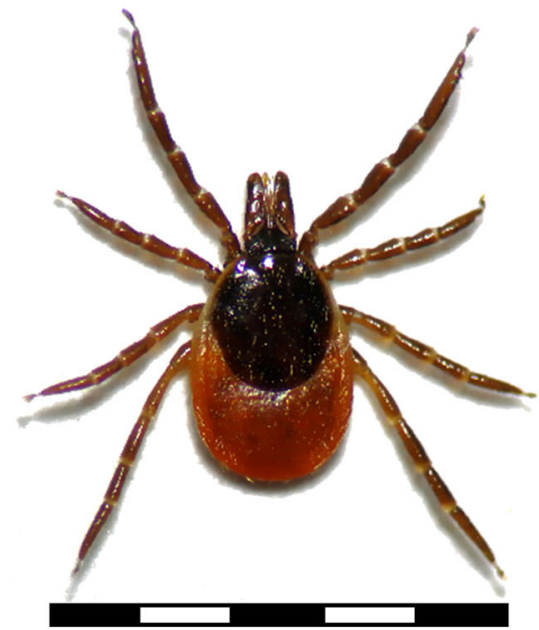

$5.0 \mathrm{~mm}$

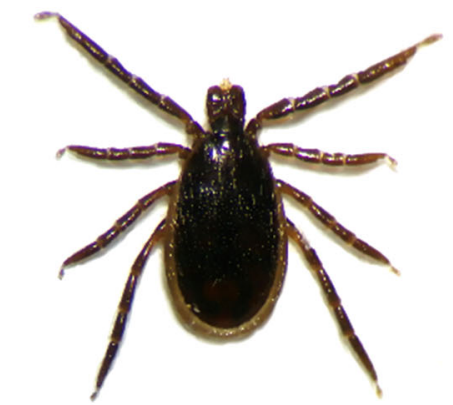

$5.0 \mathrm{~mm}$ 3c), has the widest distribution as it occurs in Africa, throughout Asia and in Eastern Europe (IZS “G. Caporale" 2009). Likewise, TBEV has a rather wide distribution, with different subtypes circulating in Ixodes ticks in Europe, Siberia and fareastern Asia (Dobler et al. 2012). Examples of highly pathogenic tick-borne viruses with a more restricted geographical distribution include Omsk haemorrhagic fever virus, transmitted by D. marginatus (Fig. 3a) and D. reticulatus (Fig. 3b) (Růžek et al. 2010) in Russia, and Kyasanur Forest virus, transmitted by Haemaphysalis spinigera (Shah et al. 2018) in India.

\section{Human and veterinary relevance of tick-borne zoo- notic pathogens}

The relevance of different tick-borne pathogens varies in the fields of human vs. veterinary medicine. For example, tickborne encephalitis (TBE) cases occur mostly in humans and only rarely in domestic animals, which are mainly regarded as sentinels of virus occurrence (Imhoff et al. 2015). However, domestic ruminants are epidemiologically important as sources of alimentary human TBEV infections (Dobler et al. 2012) and dogs as well as horses may develop severe neurological signs when contracting TBE (Pfeffer and Dobler 2011; Waldvogel et al. 1981). Regarding the numerous ticktransmitted Rickettsia spp., which are relevant globally as agents of human disease (Parola et al. 2013), evidence of pathogenicity in domestic animals is limited to Rickettsia conorii and Rickettsia rickettsii in dogs (Keenan et al. 1977; Solano-Gallego et al. 2006).

In contrast, $B$. divergens is primarily a parasite of cattle, causing haemolytic anaemia with high case fatality rates in naïve cattle herds (Springer et al. 2020; Zintl et al. 2003), whereas human $B$. divergens cases mainly involve splenectomised or immunosuppressed patients (Azagi et al.
2020). Nevertheless, cases in immunocompetent persons have also recently been reported (Martinot et al. 2011). Similarly, Ehrlichia canis is of major veterinary relevance as the causative agent of canine monocytic ehrlichiosis, whereas human ehrlichiosis cases due to this pathogen are very rare (Rar and Golovljova 2011). Similarly, A. phagocytophilum is a frequent cause of disease in dogs, horses and ruminants in Europe (Silaghi et al. 2011; Kohn et al. 2008), whereas human cases are rarely reported on the continent (Azagi et al. 2020). In North America on the other hand, human granulocytic anaplasmosis cases are numerous but tick-borne fever in ruminants has never been confirmed (Dugat et al. 2015). These epidemiological differences are attributed to different circulating strains of A. phagocytophilum (Dugat et al. 2015).

Finally, Lyme borreliosis is sometimes (subjectively) regarded as equally important in both fields, especially by dog owners, although pathogenicity for dogs has only been proven for B. burgdorferi sensu stricto (s.s.) and remains questionable for other genospecies of the B. burgdorferi s.l. complex (Littman et al. 2018).

\section{Commonly used diagnostic methods for TBDs in human and veterinary medicine}

The differences in clinical relevance of zoonotic TBDs are reflected by the availability of commercially manufactured human vs. veterinary diagnostic tests. However, as TBDs gain importance in both fields and rare zoonotic pathogens, such as Babesia spp., are increasingly identified as causes of human TBDs, a One Health approach in TBD diagnostics may lead to synergistic benefits. In the following, commonly used diagnostic techniques for TBDs in both fields and comparison of commercial availability of tests for humans vs. domestic animals are discussed, with the aim of highlighting gaps and 


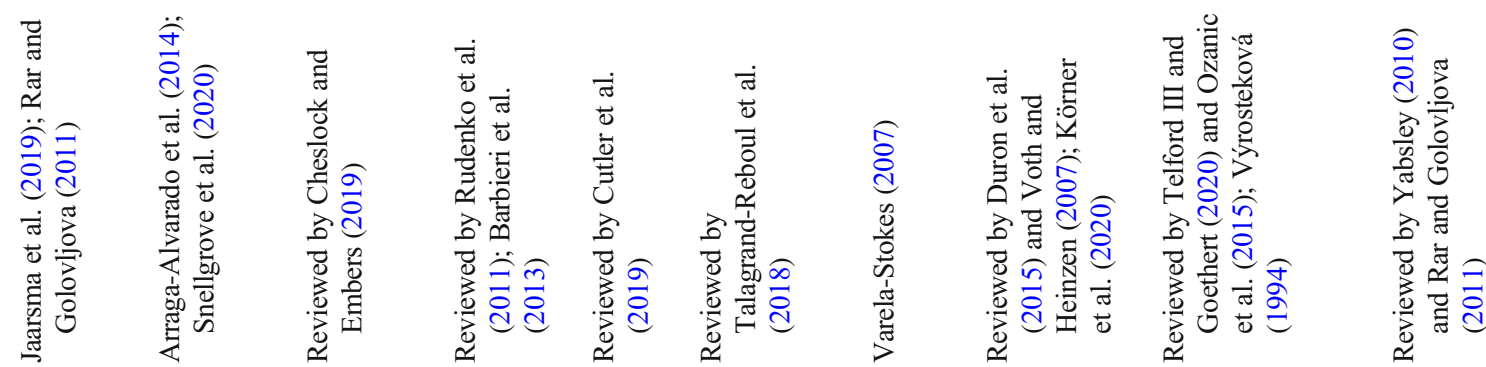

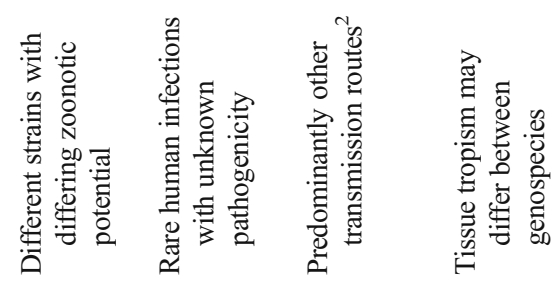

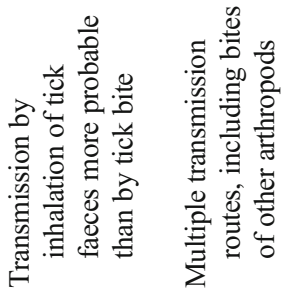

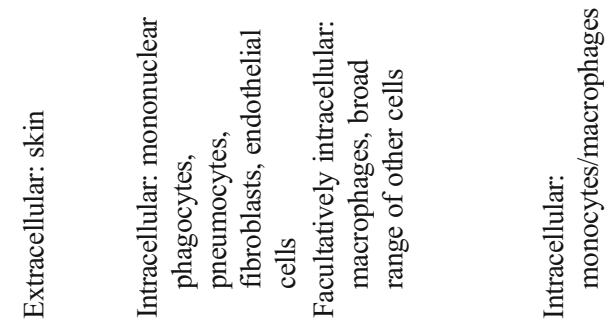

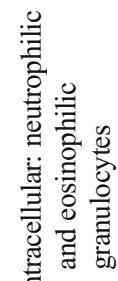

势

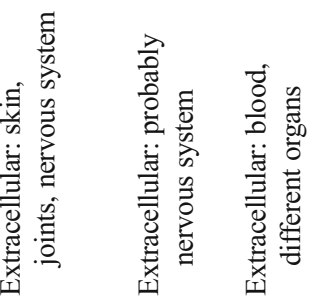
כ

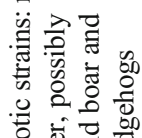

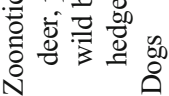

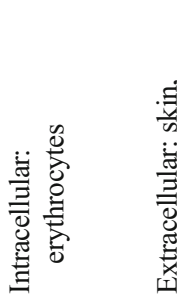

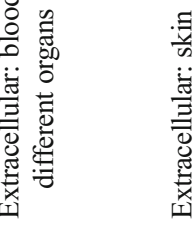

్

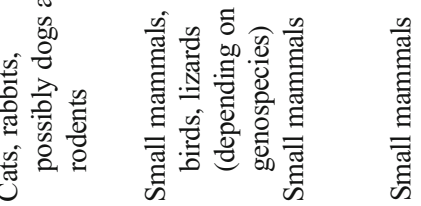

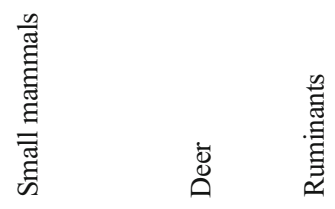

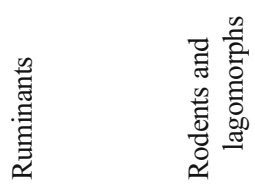

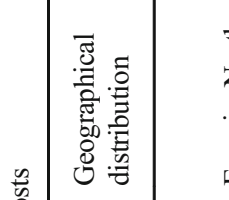

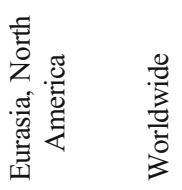

$\frac{0}{3}$

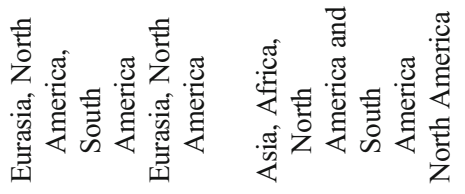

$\frac{0}{\frac{0}{0}}$

竞

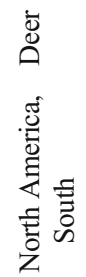

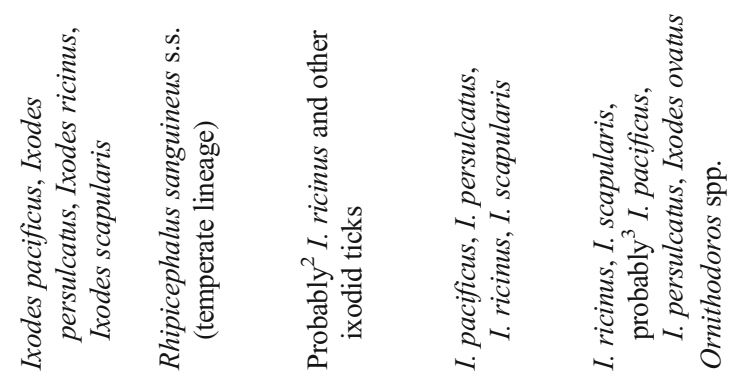
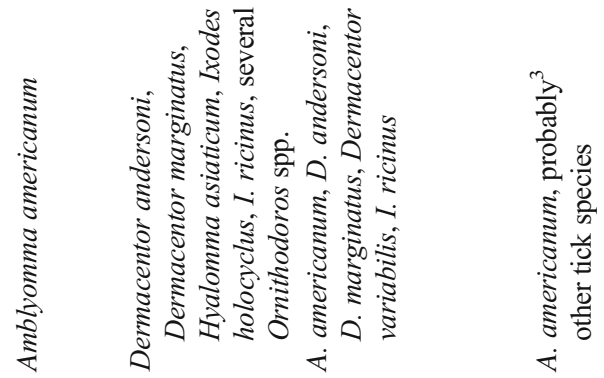

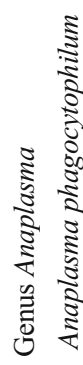




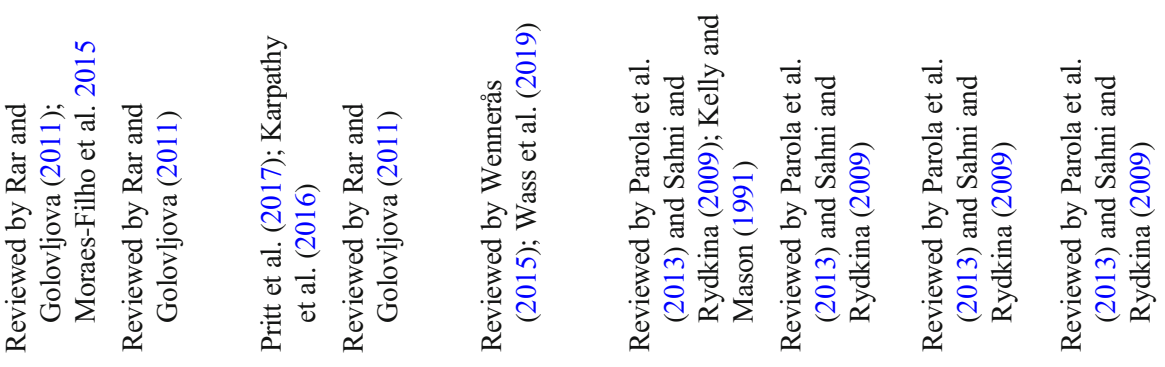<smiles>C[C@H]1[C@H](C)C[C@@H](C)[C@H]1C</smiles>

\%
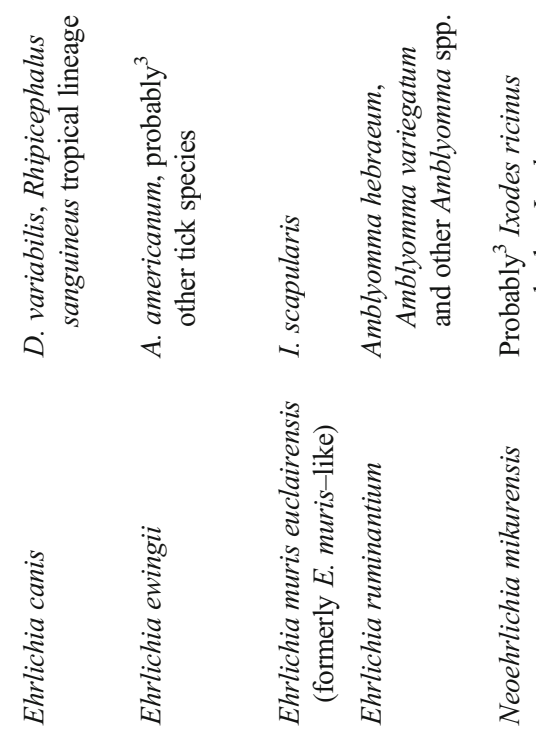

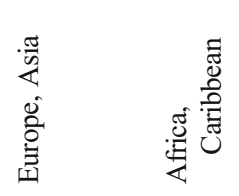

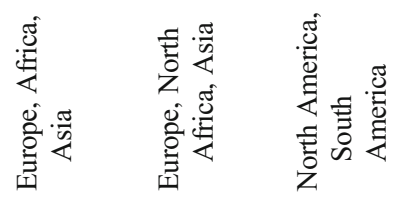
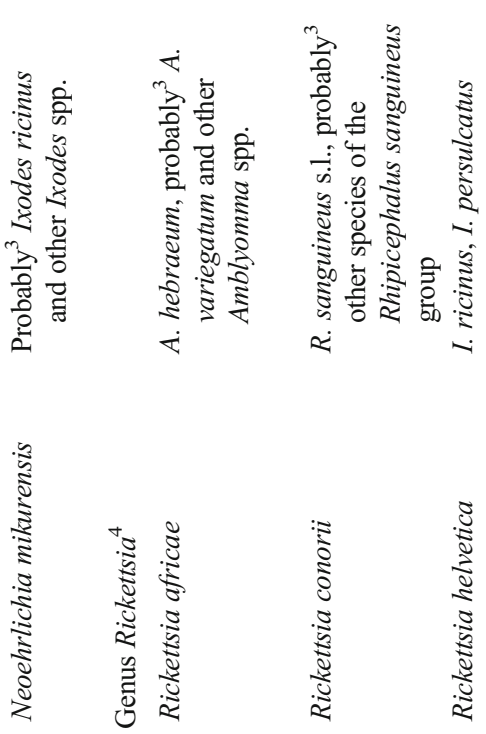

$\dot{m}$
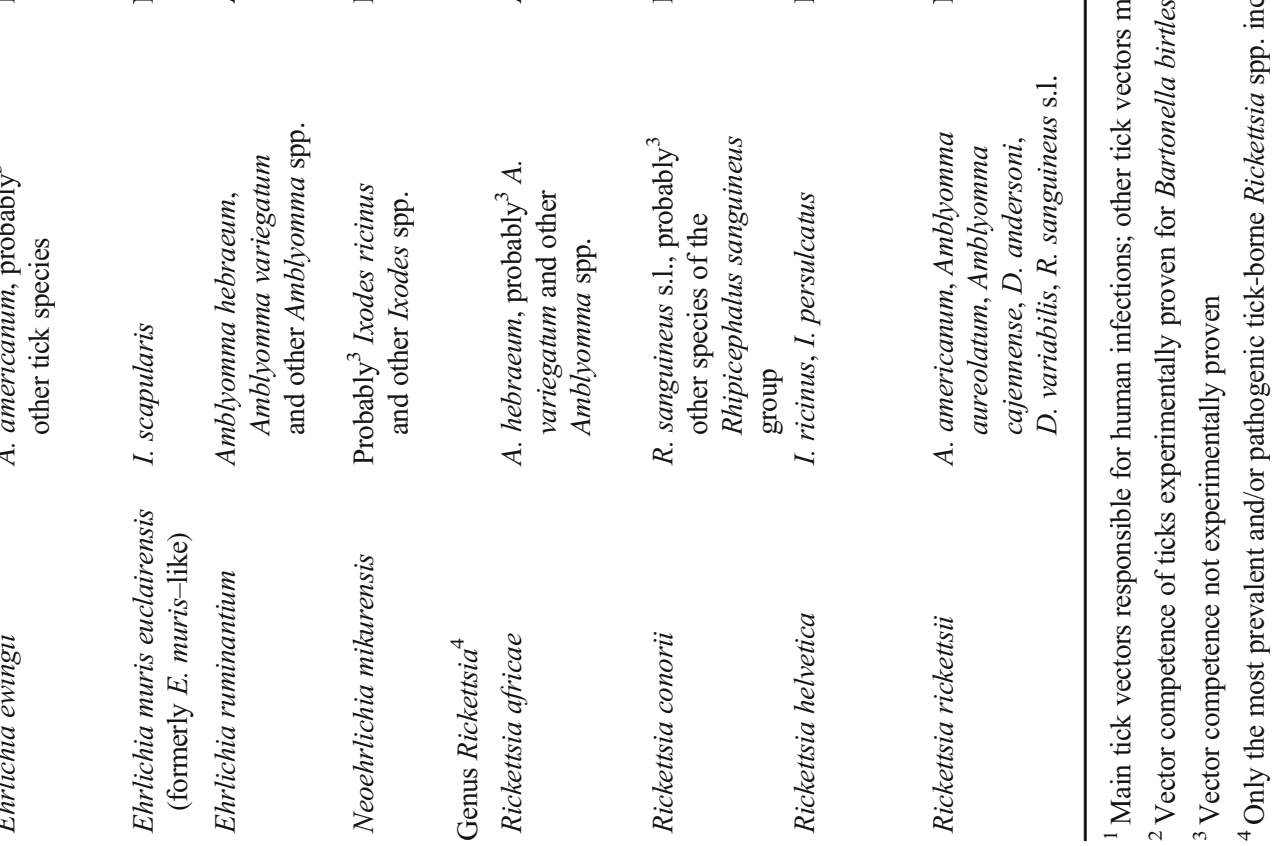
Fig. 2 Important vectors of zoonotic tick-borne bacteria (left: females, right: males). a Dermacentor variabilis, confirmed vector of Ehrlichia canis, Rickettsia rickettsii and F. tularensis. b Rhipicephalus sanguineus s.l., confirmed vector of E. canis, Rickettsia conorii and R. rickettsii. c Amblyomma hebraeum, confirmed vector of Ehrlichia ruminantium and Rickettsia africae. Photographs were taken under an OPTIKA SLX-2 stereomicroscope (OPTIKA S.r.l., Ponteranica, Italy) a
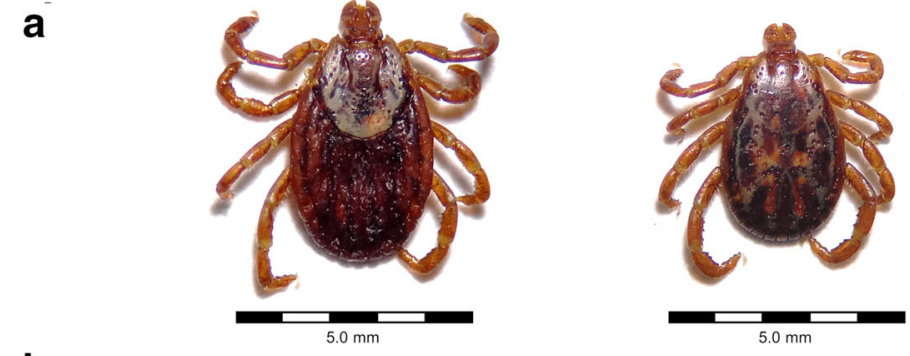

b
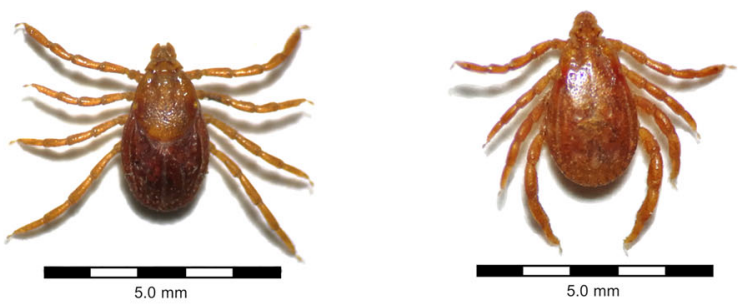

C

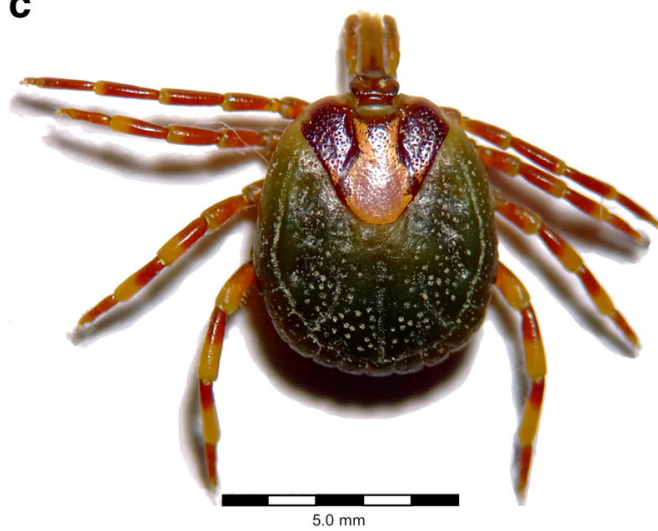

opportunities for collaboration between medical and veterinary scientists.

\section{Direct detection methods}

Traditionally, microscopy, culture of the pathogen or xenodiagnosis was widely used for direct detection of tick-borne pathogens in patient samples, but nowadays, nucleic acidbased methods are more commonly employed. Nevertheless, microscopic examination of stained blood smears is still the method of first choice for diagnosis of acute Babesia infections, in both human and veterinary medicine (Ord and Lobo 2015; Solano-Gallego et al. 2016). Furthermore, blood smear analysis is helpful to demonstrate intracellular morulae during anaplasmosis and ehrlichiosis (Schotthoefer et al. 2013). This method is relatively fast and low-cost; however, sensitivity depends on the level of parasitaemia and pathogen species differentiation is not always possible (Ord and Lobo 2015). Therefore, diagnosis should be corroborated by molecular techniques (Solano-Gallego et al. 2016).

Pathogen culture can be difficult and time consuming, may require special biosafety conditions and is therefore often performed by specialised laboratories only. Many tick-borne pathogens grow slowly and require special media or cell cultures. For example, the time to positive culture may span several weeks for B. burgdorferi s.l. (Eldin et al. 2019) and up to 30 days for Rickettsia spp. (Portillo et al. 2017). Challenges associated with culturing tick-borne pathogens are further illustrated by the example of Neoehrlichia mikurensis, which was only recently successfully cultured in human and tick cell lines, although the pathogen has been known since 2004 (Wass et al. 2019).

Nucleic acid amplification techniques are often more sensitive than the aforementioned methods and considerably faster than pathogen culture, improving diagnostic efficiency (Korber et al. 2017). In routine diagnostic settings, real-time quantitative PCR (qPCR) is often used due to increased sensitivity and speed as compared to conventional PCR. Additionally, real-time qPCR allows quantification by the gene copy numbers of the given pathogen or cycle threshold $(\mathrm{Ct})$ values and can therefore also be useful for monitoring the course of infection (Che et al. 2019). However, it should be kept in mind that detection of DNA does not necessarily indicate that viable pathogens are present, and false-positive results may be obtained after successful treatment (Kuleš et al. 2017). 
Fig. 3 Important vectors of zoonotic tick-borne viruses (left: females, right: males). a Dermacentor marginatus, confirmed vector of Crimean-Congo haemorrhagic fever virus (CCHFV) and Omsk haemorrhagic fever virus (OHFV). b Dermacentor reticulatus, confirmed vector of OHFV and tick-borne encephalitis virus. c Hyalomma rufipes, confirmed vector of CCHFV. Photographs were taken under an OPTIKA SLX-2 stereomicroscope (OPTIKA S.r.1., Ponteranica, Italy) a
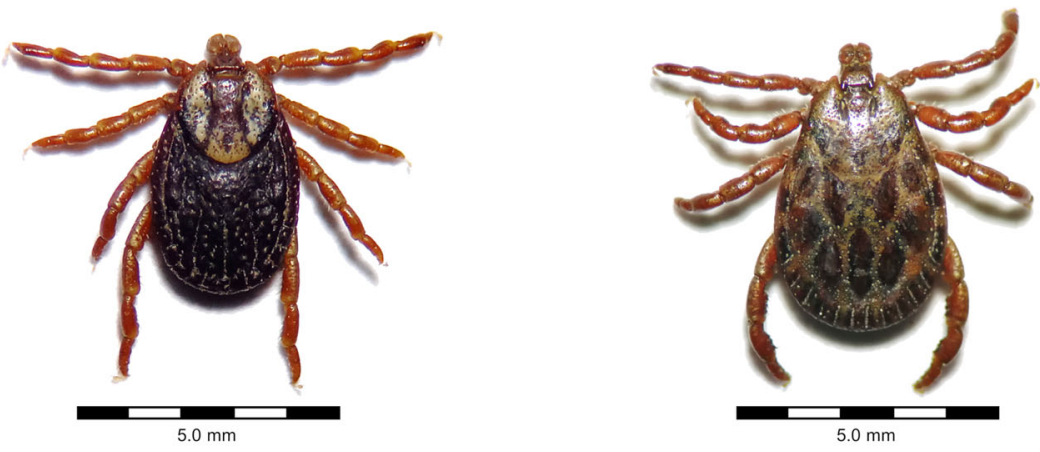

b
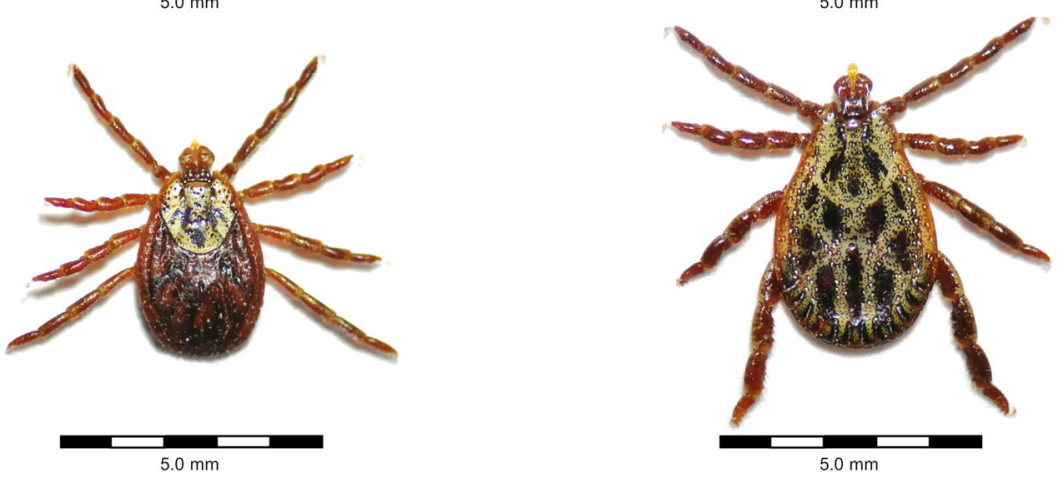

c
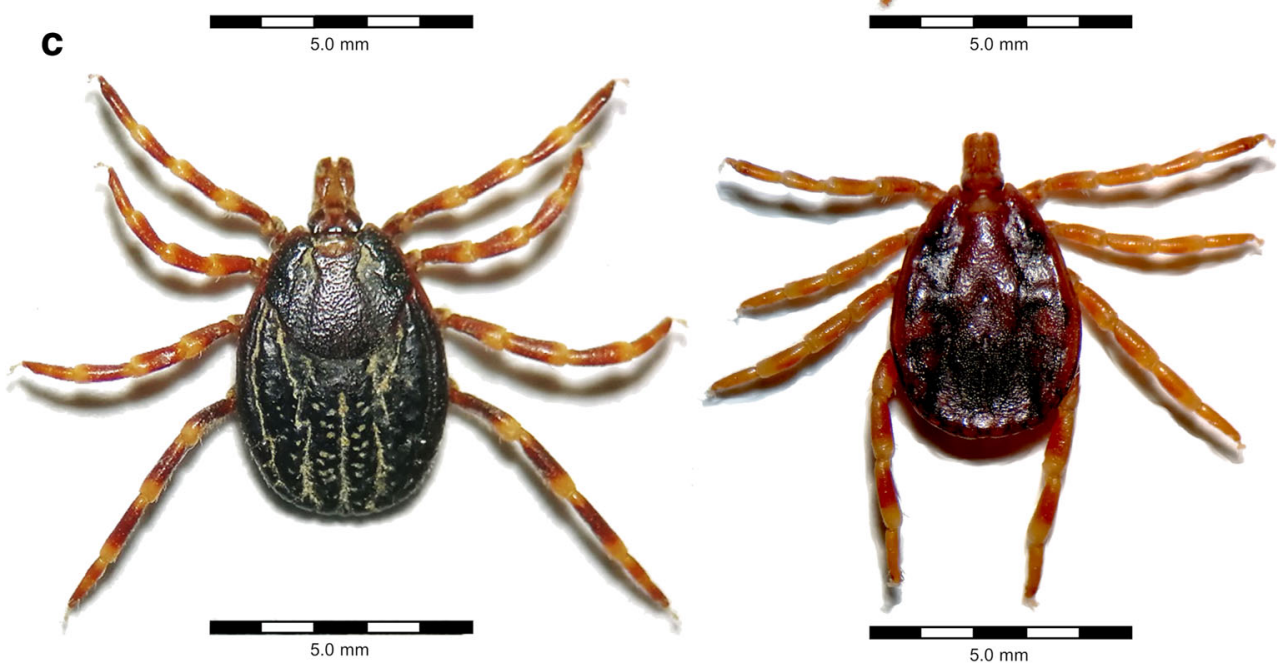

Adaptations of the real-time qPCR method include digital PCR (dPCR), which allows detection and quantification of rare target sequences by partitioning the sample into many parallel PCR reactions, thus improving test sensitivity. This technique has recently been successfully applied for B. burgdorferi s.l. identification in patient blood, which was previously hindered by extremely low numbers of circulating spirochaetes (Das et al. 2020).

Aside from singleplex PCRs, multiplex assays may be used as screening tests. For example, multiplex assays combining real-time qPCR detection of A. phagocytophilum with Ehrlichia spp. or B. burgdorferi s.l. are available (e.g. Courtney et al. 2004; Reller and Dumler 2018), while a broad-panel system for the simultaneous detection of nine tick-borne pathogens is currently available for research use only (Buchan et al. 2019). For patients suspected of sepsis, multiplex real-time qPCRs for simultaneous amplification of a wide range of pathogens have been developed (Guido et al. 2016); however, not all of them detect tick-borne pathogens. Recently, multiplex PCR followed by electrospray ionisation mass spectrometry (PCR/ESI-MS) has been used to diagnose early B. burgdorferi s.s. (Eshoo et al. 2012), Ehrlichia spp. and $R$. rickettsii (Eshoo et al. 2010) as well as A. phagocytophilum (Lagler et al. 2017) infections. This technique provides the advantage of identifying and genotyping pathogens in a short time, but it was only adopted by a few hospitals in Europe and was discontinued by the manufacturer in 2017, probably due to economic reasons (Özenci et al. 2017).

In general, PCR requires expensive equipment, which may be a problem in less-developed countries or in field settings. Loop-mediated isothermal amplification (LAMP) is a low- 


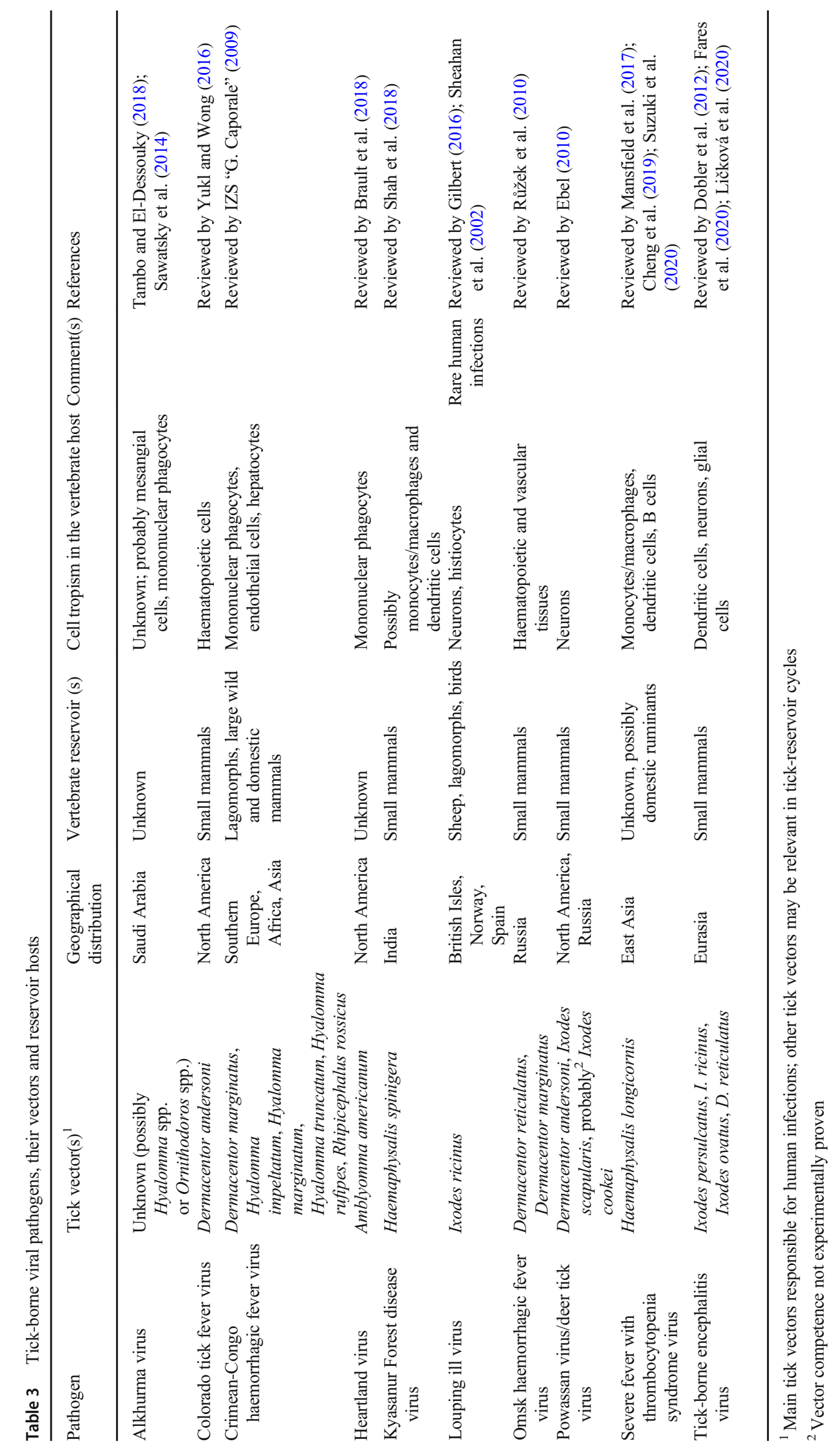


cost DNA amplification technique that works at a constant temperature and thus does not require a thermocycler (Becherer et al. 2020). LAMP assays to detect tick-borne pathogens have mainly been developed not only for veterinary applications (e.g. Faggion et al. 2013; Singh et al. 2019; Wang et al. 2017) but also for detection of TBEV (Hayasaka et al. 2013) and severe fever with thrombocytopenia syndrome virus (SFTSV) (Baek et al. 2018) in human patients in resource-limited settings.

Mass spectrometry-based approaches, e.g. matrix-assisted laser desorption ionisation time-of-flight (MALDI-TOF), are routinely used to identify cultured pathogens in microbiological laboratories, based on comparison of protein signatures to existing databases. Although not yet routinely used for diagnosis of TBDs, applicability for identification and typing of cultured B. burgdorferi s.l. has recently been demonstrated (Neumann-Cip et al. 2020). Mass spectrometry also offers new opportunities to identify biomarkers of specific diseases in patient samples, as shown, for example, for Babesia microti infections in an experimental hamster model (Magni et al. 2020). Similarly, MALDI-TOF analysis of canine serum samples may aid in the diagnosis of Babesia canis infections in dogs (Adaszek et al. 2014).

\section{Indirect detection methods: detection of humoral immune response}

In some TBDs, direct pathogen detection is particularly difficult. For example, B. burgdorferi s.l. spirochaetes are only present at transient and low levels in patient blood (Schutzer et al. 2018). Similarly, direct detection of TBEV is only possible in the early, viraemic phase of the disease (Girl et al. 2020). Therefore, serological tests are commonly employed in TBD diagnosis. However, it has to be kept in mind that there is usually a time lag of several days to weeks between disease onset and development of antibody and, furthermore, that elevated antibody levels indicate pathogen exposure, but not necessarily current infection. Therefore, positive titres should always be interpreted in conjunction with the clinical presentation (Portillo et al. 2017; Sanchez et al. 2016). Acute infections may be detected by seroconversion or a rise in antibody titres. Therefore, testing of sequential samples taken several weeks apart is often recommended (e.g. Portillo et al. 2017; Solano-Gallego et al. 2016). IgM antibody titres are the first to rise and may therefore be targeted during early phases of the infection. However, IgM antibody tests are particularly prone to produce false-positive results and should thus be accompanied by other methods, e.g. direct pathogen detection or documentation of IgG seroconversion (Landry 2016; Seriburi et al. 2012). IgG avidity testing represents an additional approach to determine the stage of an infection, as $\operatorname{IgG}$ binding avidity increases as the infection progresses. For TBE, IgG avidity testing may be useful to rule out false-positive results due to cross-reactive IgM antibodies induced by other flaviviruses or in cases of atypical antibody responses, e.g. when IgM antibodies are persistently elevated past the acute phase of infection (Vilibic-Cavlek et al. 2016). For Lyme borreliosis, a recently developed IgG avidity Western blot has shown promising first results to identify disease stage (Mavin et al. 2018).

The most frequently used serologic methods include the enzyme-linked immunosorbent assay (ELISA), immunofluorescence antibody test (IFAT) and immunoblotting. ELISA tests can be performed with high sample throughput but may suffer from lower specificity as compared to other tests. Therefore, a two-tiered approach is often recommended, confirming positive or borderline ELISA tests with more specific techniques such as immunoblotting (e.g. in Lyme borreliosis, Sanchez et al. 2016) or seroneutralisation tests (e.g. in TBE, Reusken et al. 2019).

Modifications of the ELISA technique include magnetic bead-based multianalyte assays, which are characterised by high sensitivity even if antibody titres are low. Bead-based assays have been developed, for example, for the detection of anti-B. burgdorferi s.l. antibodies in humans (Gerritzen and Brandt 2012) as well as in horses and dogs (Wagner et al. 2011a; Wagner et al. 2011b).

For rickettsial diseases, the IFAT is considered the serological reference method (Portillo et al. 2017). IFATs are also commonly employed to detect and quantify anti-Babesia (Sanchez et al. 2016; Solano-Gallego et al. 2016) as well as anti-Ehrlichia antibodies (Dumler et al. 2007). However, the technique is relatively labour intensive as compared to ELISA and can be somewhat subjective as it involves microscopic evaluation of antigen-coated glass slides.

In addition, rapid immunochromatographic tests are commercially available for non-laboratory settings. These tests are easy to use; however, they offer only a positive/negative result, allowing no quantification of antibody titres. Furthermore, some commercially available rapid tests suffer from low sensitivity, as shown e.g. for Lyme borreliosis (Liu et al. 2018; Smit et al. 2015).

Sensitivity and specificity of serologic tests greatly depend on the antigen(s) used. Use of purified or recombinant antigens as well as synthetic peptides rather than whole-cell lysates may improve specificity. For example, ELISA tests based on a synthetic C6 peptide, a highly invariant region of the $B$. burgdorferi s.l. VlsE (variable major protein-like sequence, expressed) protein, have superior specificity as opposed to whole-cell antigen ELISAs (Waddell et al. 2016). However, cross-reactivity with sera from Borrelia miyamotoi-infected patients has recently been described (Molloy et al. 2017). In dogs, for which B. burgdorferi s.s. and s.l. (Borrelia afzelii and Borrelia garinii) vaccines are available, use of the $\mathrm{C} 6$ peptide in serological tests allows discrimination between vaccinated and infected animals 
(Pantchev et al. 2015). In human TBDs, discrimination between infection-induced and vaccination-induced antibodies is relevant for TBE. For this purpose, an ELISA based on the non-structural protein 1 (NS1) of TBEV has recently been developed, which is exclusively indicative of natural infection and also allows significant discrimination from other flavivirus infections (Girl et al. 2020).

Similar to direct tests, serological assays such as immunoblots and rapid immunochromatographic tests are also available in multiplex formats. For example, a rapid test frequently employed in veterinary medicine allows the simultaneous detection of canine antibodies against B. burgdorferi s.l., Ehrlichia spp. and Anaplasma spp., in addition to canine heartworm antigen (Chandrashekar et al. 2010).

\section{Indirect detection methods: detection of cellular immune response}

Aside from antibody production, many tick-borne pathogens induce specific $\mathrm{T}$ cell responses. T cell-based assays might be helpful to bridge the gap between infection and onset of antibody production or might be employed as confirmatory tests to rule out false-positive serology results (Jin et al. 2013). The enzyme-linked immunospot assay (ELISPOT) is a sensitive method to measure the cytokine response of $\mathrm{T}$ cells upon antigen stimulation (Kalyuzhny 2005). ELISPOT assays have been developed for a variety of TBDs; however, their utility is controversially discussed, especially regarding Lyme borreliosis. ELISPOT assays developed for Lyme borreliosis, which exclusively measure interferon- $\gamma$ release, show a wide range of sensitivity and specificity and poor reproducibility and are therefore currently not recommended for routine diagnostic use (Raffetin et al. 2020). Similarly, lymphocyte transformation tests (LTTs) assess the proliferative response of T cells upon stimulation with specific antigens. LTTs are offered by some laboratories for diagnosis of active Lyme borreliosis in humans; however, current guidelines do not recommend these tests due to low specificity (Dessau et al. 2014).

Cytokines and chemokines as evidence of a cellular immune response may also be measured directly in patient samples. For example, the chemokine CXCL13 in cerebrospinal fluid constitutes a sensitive and specific marker of acute Lyme neuroborreliosis in humans (Raffetin et al. 2020).

\section{Relevant zoonotic TBDs and commercial availability of diagnostic test kits by the example of Germany}

In Germany, as in other central European countries, I. ricinus is the most relevant vector of zoonotic tick-borne pathogens, including B. burgdorferi s.1., B. miyamotoi, A. phagocytophilum, Rickettsia helvetica, B. divergens,
B. microti, Babesia venatorum and TBEV (Rizzoli et al. 2014). With an estimate of 60,000-100,000 total and 7500 hospitalised cases annually, Lyme borreliosis is regarded as the most frequent human TBD in Germany (Lohr et al. 2015). However, since only certain manifestations of Lyme borreliosis are reportable in some, but not all, federal states, this number may be inaccurate (Lohr et al. 2015). In contrast, TBE is notifiable in all parts of Germany and annual case numbers ranged between 195 and 584 in the period 20012019 (Robert Koch-Institut 2020). Less is known regarding other TBDs in Germany, but human cases of neoehrlichiosis (von Loewenich et al. 2010) and babesiosis due to B. venatorum (Häselbarth et al. 2007) and B. microti (Hildebrandt et al. 2007) have been reported during the past decades. With regard to Rickettsia spp., R. helvetica is the predominant species, but Rickettsia monacensis, Rickettsia slovaca and Rickettsia raoultii also occur in Germany (Dobler and Pfeffer 2012). In addition, travellers returning from other countries may be infected with non-endemic tickborne pathogens, e.g. Rickettsia africae (Antal et al. 2013), necessitating appropriate diagnostic possibilities.

Regarding veterinary medicine, no estimates of annual TBD incidence exist. However, granulocytic anaplasmosis is regarded as the most important TBD in dogs, whereas Lyme borreliosis may be overdiagnosed (Gerber et al. 2009). Furthermore, A. phagocytophilum is relevant as the causative agent of granulocytic anaplasmosis in horses (Silaghi et al. 2011) and tick-borne fever in ruminants (Nieder et al. 2012). In ruminants, redwater fever due to $B$. divergens occurs sporadically and may lead to significant mortality in naïve cattle herds (Springer et al. 2020). In addition, sporadic clinical cases of TBE have been described in German dogs (Reiner and Fischer 1998; Saenger et al. 2013).

Commercially available diagnostic kits, taking Germany as an example, were identified by Google Search using combinations of the following keywords: Anaplasma, Babesia, Borrelia, Rickettsia, Ehrlichia, TBE, FSME, IgG, IgM, PCR, ELISA, ELISPOT, IFAT, serology and kit. Furthermore, a list of available diagnostic tests for B. burgdorferi s.1. and TBEV was obtained from the German National Reference Center for Borrelia and the German National Consiliary Laboratory for TBEV, respectively. In addition, the German Diagnostics Industry Association contributed a list of relevant manufacturers, whose websites were searched for relevant test kits.

In Table 4, the relative quantities of commercially available diagnostic test kits for human vs. veterinary use for each pathogen are shown. Only tests designed for patient samples were included, i.e. tests for pathogen detection in ticks were not considered, since a positive result in the detached tick is not a reliable indicator of human or animal infection. In-house tests and research-use only tests were also not considered. No absolute numbers are shown, because we cannot guarantee 
Table 4 Relative quantity of commercially available diagnostic tests for zoonotic tick-borne pathogens in Germany

\begin{tabular}{|c|c|c|c|c|c|c|}
\hline \multirow[t]{2}{*}{ Pathogen } & \multicolumn{2}{|c|}{ Nucleic acid detection } & \multicolumn{2}{|l|}{ Antibody detection } & \multicolumn{2}{|c|}{$\begin{array}{l}\text { Other tests } \\
\text { (e.g. ELISPOT) }\end{array}$} \\
\hline & $\begin{array}{l}\text { For } \\
\text { veterinary } \\
\text { (vet.) use }\end{array}$ & $\begin{array}{l}\text { For } \\
\text { human } \\
\text { use }\end{array}$ & For vet. use & For human use & $\begin{array}{l}\text { For } \\
\text { vet. } \\
\text { use }\end{array}$ & $\begin{array}{l}\text { For } \\
\text { human } \\
\text { use }\end{array}$ \\
\hline Babesia divergens & - & + & $\begin{array}{c}\text { + (IgG: +, IgM: }-, \\
\text { IgG/IgM: -) }\end{array}$ & - & - & - \\
\hline Babesia microti & - & + & $\begin{array}{c}\text { + (IgG: +, IgM: }-, \\
\text { IgG/IgM: -) }\end{array}$ & $+(\operatorname{IgG}:+, \operatorname{IgM}:-, \operatorname{IgG} / \operatorname{IgM}:-)$ & - & + \\
\hline Babesia venatorum & - & + & - & - & - & - \\
\hline Bartonella henselae $^{1}$ & - & + & $\begin{array}{c}+ \text { (IgG: +, IgM: }-, \\
\text { IgG/IgM: -) }\end{array}$ & $+(\operatorname{IgG}:+, \operatorname{IgM}:+, \operatorname{IgG} / \operatorname{IgM}:-)$ & - & + \\
\hline Borrelia burgdorferi s.1. & + & ++ & ++ (IgG: ++, IgM: +, IgG/IgM: +) & +++ (IgG: +++, IgM: +++, IgG/IgM: ++) & + & + \\
\hline Borrelia miyamotoi & - & - & - & - & - & + \\
\hline Coxiella burnetii & ++ & - & ++ (IgG: ++, IgM: +, IgG/IgM: -) & +++ (IgG: ++, IgM: ++, IgG/IgM: -) & - & - \\
\hline Francisella tularensis & - & + & $\begin{array}{c}\text { + (IgG: +, IgM: - } \\
\text { IgG/IgM: -) }\end{array}$ & ++ (IgG: ++, IgM: +, IgG/IgM: -) & - & - \\
\hline $\begin{array}{l}\text { Anaplasma } \\
\text { phagocytophilum }\end{array}$ & + & + & ++ (IgG: ++, IgM: -, IgG/IgM:-) & ++ (IgG: ++, IgM: +, IgG/IgM: -) & - & \\
\hline Ehrlichia spp. & + & - & ++ (IgG: ++, IgM: -, IgG/IgM: -) & + (IgG: +, IgM: +, IgG/IgM: -) & - & + \\
\hline Neoehrlichia mikurensis & - & - & - & - & - & - \\
\hline Rickettsia spp. & - & ++ & ++ (IgG: ++, IgM: -, IgG/IgM:-) & $\begin{array}{l}\text { ++ (IgG: ++, IgM: ++, } \\
\text { IgG/IgM: -) }\end{array}$ & - & - \\
\hline $\begin{array}{l}\text { Tick-borne } \\
\text { encephalitis virus }\end{array}$ & + & + & $\begin{array}{c}+ \text { (IgG: +, IgM: }-, \\
\text { IgG/IgM: -) }\end{array}$ & $\begin{array}{l}+++(\operatorname{IgG}:++, \operatorname{IgM}:++ \\
\quad \text { IgG/IgM: }+ \text { ) }\end{array}$ & - & - \\
\hline
\end{tabular}

,$+++>20$ kits on the market;,$++ 6-20$ kits on the market;,$+ \leq 5$ kits on the market; -, no marketed kits found

${ }^{1}$ Vector competence of ticks for $B$. henselae not proven

that the search was exhaustive and, furthermore, the market is subject to frequent changes.

Results indicate that a multitude of serologic kits and, to a lesser extent, nucleic acid detection kits are available for diagnosis of Lyme borreliosis and TBE in humans in Germany (Table 4). A rather large number of kits was also retrieved for Lyme borreliosis in animals, but only few for TBE, although domestic animals have proven useful as sentinels of human disease risk (Imhoff et al. 2015). In addition, most veterinary serology kits for B. burgdorferi s.l. detect IgG antibodies only, whereas an equal amount of $\operatorname{IgG}$ and $\operatorname{IgM}$ tests exists for humans. This can be explained by the fact that animals usually do not develop acute disease after B. burgdorferi s.l. exposure, and IgM testing is thus not recommended (Littman et al. 2018). However, a positive $\operatorname{IgG}$ titre is not an indicator of active infection and it can be extremely difficult to determine whether clinical disease in animals is actually due to Borrelia infection (Divers 2013; Littman et al. 2018). To reduce unnecessary antibiotic use, reliable tests indicative of active infection would be extremely helpful in both disciplines. As highlighted above, IgG avidity testing or improved PCR procedures, such as digital PCR, could be promising approaches.

Regarding A. phagocytophilum, a similar amount of serologic as well as nucleic acid detection kits was identified for the human medical as well as the veterinary market, probably because A. phagocytophilum plays an important role in veterinary medicine, affecting several species as described above. The number of available veterinary serology kits for Ehrlichia spp. even exceeded the amount available for use in human medicine, but no direct detection kits for Ehrlichia spp. were identified for veterinary use. Ticks transmitting zoonotic Ehrlichia spp. (Rhipicephalus sanguineus s.l., A. americanum) are not endemic in Germany; thus, ehrlichioses are only relevant as imported diseases. E. canis is a major threat to canine health worldwide (Rar and Golovljova 2011), including in Mediterranean Europe from where many dogs are imported to Germany and other Central or Northern European countries. In contrast, human ehrlichiosis cases are rather rare, occurring mainly in North America (Rar and Golovljova 2011), and are thus more rarely imported to Germany than canine cases. Consequently, the available veterinary kits were mostly designed for E. canis antibody detection.

In contrast, only few kits for the diagnosis of rickettsioses in animals were identified, probably because it is unknown whether Rickettsia spp. cause disease in animals, with the exception of $R$. conorii and $R$. rickettsii in dogs (Keenan et al. 1977; Solano-Gallego et al. 2006). Neither of these species is endemic in Germany (Dobler and Pfeffer 2012). Regarding humans, several serologic as well as direct detection kits for tick-borne Rickettsia spp. were identified, mainly designed for $R$. rickettsii and $R$. conorii detection.

Particularly few diagnostic kits were identified regarding infections with zoonotic Babesia spp., both in the human medical and in the veterinary sector. This may be due to the fact that Babesia infections are often diagnosed by blood smears and/or 
in-house PCR tests in acute cases. However, blood smears have a limited sensitivity when parasitaemia is low or limited specificity when parasite morphology has been altered due to refrigeration prior to blood smear preparation (Cursino-Santos et al. 2014). In addition, many human babesiosis cases in immunocompetent individuals might be overlooked when symptoms are mild, which represents a problem regarding blood transfusions, for example (Hildebrandt et al. 2008; Ord and Lobo 2015). In the veterinary field, a recent outbreak of bovine babesiosis (B. divergens) in Germany has shown that mortality rates and the subsequent economic impact may be high if diagnosis is delayed (Springer et al. 2020). Therefore, sensitive, easy-touse and rapid diagnostic tools for zoonotic Babesia spp. are needed. Recently, an immunochromatographic test based on a recombinant $B$. microti surface antigen showed promising results in experimentally infected mice (Cai et al. 2018).

Regarding B. miyamotoi and N. mikurensis, which have only recently been identified as human and, possibly, veterinary pathogens (Diniz et al. 2011; Platonov et al. 2011; Welinder-Olsson et al. 2010), no commercially available kits were identified at all, except for one ELISPOT kit designed for B. miyamotoi. In general, only few ELISPOT assays are currently available in Germany, reflecting the fact that their utility is controversially discussed. Identified tests included EPISPOTS for detecting cellular immunity against $B$. burgdorferi s.l. in humans, horses and dogs, as well as against B. miyamotoi, B. microti, Ehrlichia spp. and Bartonella henselae in humans.

For Bartonella henselae, C. burnetii and F. tularensis, tickborne transmission plays a minor role. Several diagnostic kits were identified for $C$. burnetii for both disciplines, as this pathogen is economically important as a cause of abortions in ruminants as well as from a public health perspective (Duron et al. 2015). In contrast, identified diagnostic kits for $F$. tularensis were mainly for human use, as symptomatic infections in domestic animals are limited to cats and rabbits (Telford III and Goethert 2020).

\section{Conclusions}

Human and animal health are closely linked by ticks acting as vectors for zoonotic pathogens, making tick-borne diseases excellent examples of the One Health concept. Animals are either clinically affected by the same tick-borne pathogens as humans and/or play a role in tick cycle maintenance and as reservoirs or sentinel pathogen hosts. Using the German market as an example, several gaps in commercial availability of diagnostic tests for zoonotic tick-borne pathogens were identified. Regarding B. burgdorferi s.l., sensitive tests indicative of active infection would be useful to limit unnecessary or overuse of antibiotics in human as well as veterinary medicine. Furthermore, there is a need for rapid and sensitive diagnostic tools for zoonotic Babesia spp. infections in both disciplines. Recently emerged tick-borne pathogens, such as $N$. mikurensis and B. miyamotoi, open up further opportunities for collaboration, since no standardised tests for these pathogens are yet commercially available. Test development for these pathogens could save substantial time and effort for the benefit of both human and animal health.

Acknowledgements The authors are grateful to Volker Fingerle (German National Reference Center for Borrelia, Oberschleissheim, Germany) and Gerhard Dobler (German National Consiliary Laboratory for TBEV, Munich, Germany) for providing information on available B. burgdorferi s.l. and TBEV diagnostic kits, respectively. Furthermore, the authors thank Carolin Schächterle (German Diagnostics Industry Association, Berlin, Germany) for providing information on relevant test manufacturers. Open Access funding enabled and organized by Projekt DEAL.

Authors' contributions CS designed the study. AS, AG and JP collected the data on available diagnostic tests. AS drafted the manuscript, and CS, AG and JP reviewed the manuscript. All authors read and approved the final manuscript.

Funding This study was supported by a grant of the European Union through the European Regional Development Fund and the Interreg North Sea Region Programme 2014-2020 as part of the NorthTick project (reference number J-No.: 38-2-7-19).

\section{Compliance with ethical standards}

Conflict of interest The authors declare that they have no conflict of interest.

Open Access This article is licensed under a Creative Commons Attribution 4.0 International License, which permits use, sharing, adaptation, distribution and reproduction in any medium or format, as long as you give appropriate credit to the original author(s) and the source, provide a link to the Creative Commons licence, and indicate if changes were made. The images or other third party material in this article are included in the article's Creative Commons licence, unless indicated otherwise in a credit line to the material. If material is not included in the article's Creative Commons licence and your intended use is not permitted by statutory regulation or exceeds the permitted use, you will need to obtain permission directly from the copyright holder. To view a copy of this licence, visit http://creativecommons.org/licenses/by/4.0/.

\section{References}

Adaszek Ł, Banach T, Bartnicki M, Winiarczyk D, Łyp P, Winiarczyk S (2014) Application the mass spectrometry MALDI-TOF technique for detection of Babesia canis canis infection in dogs. Parasitol Res 113:4293-4295. https://doi.org/10.1007/s00436-014-4124-1

Antal AS, Flaig MJ, Schneck C, Thoma B, Herzinger T (2013) Souvenir from South Africa. Infection 41:597-598. https://doi.org/10.1007/ s15010-013-0425-Z

Arraga-Alvarado CM, Qurollo BA, Parra OC, Berrueta MA, Hegarty BC, Breitschwerdt EB (2014) Molecular evidence of Anaplasma platys infection in two women from Venezuela. Am J Trop Med Hyg 91: 1161-1165. https://doi.org/10.4269/ajtmh.14-0372

Azagi T, Hoornstra D, Kremer K, Hovius JWR, Sprong H (2020) Evaluation of disease causality of rare Ixodes ricinus-borne 
infections in Europe. Pathogens 9:150. https://doi.org/10.3390/ pathogens 9020150

Baek YH, Cheon HS, Park SJ, Lloren KKS, Ahn SJ, Jeong JH, Choi WS, Yu MA, Kwon HI, Kwon JJ, Kim EH, Kim YI, Antigua KJC, Kim SY, Jeong HW, Choi YK, Song MS (2018) Simple, rapid and sensitive portable molecular diagnosis of SFTS virus using reverse transcriptional loop-mediated isothermal amplification (RTLAMP). J Microbiol Biotechnol 28:1928-1936. https://doi.org/10. 4014/jmb.1806.06016

Barbieri AM, Venzal JM, Marcili A, Almeida AP, González EM, Labruna MB (2013) Borrelia burgdorferi sensu lato infecting ticks of the Ixodes ricinus complex in Uruguay: first report for the Southern Hemisphere. Vector Borne Zoonotic Dis 13:147-153. https://doi.org/10.1089/vbz.2012.1102

Becherer L, Borst N, Bakheit M, Frischmann S, Zengerle R, von Stetten F (2020) Loop-mediated isothermal amplification (LAMP) - review and classification of methods for sequence-specific detection. Anal Methods 12:717-746. https://doi.org/10.1039/C9AY02246E

Brault AC, Savage HM, Duggal NK, Eisen RJ, Staples JE (2018) Heartland virus epidemiology, vector association, and disease potential. Viruses 10:498. https://doi.org/10.3390/v10090498

Buchan BW, Jobe DA, Mashock M, Gerstbrein D, Faron ML, Ledeboer NA, Callister SM (2019) Evaluation of a novel multiplex highdefinition PCR assay for detection of tick-borne pathogens in whole-blood specimens. J Clin Microbiol 57:e00513-e00519. https://doi.org/10.1128/jcm.00513-19

Cai Y et al (2018) Molecular characterization of Babesia microti seroreactive antigen 5-1-1 and development of rapid detection methods for anti- $B$. microti antibodies in serum. Acta Trop 185: 371-379. https://doi.org/10.1016/j.actatropica.2018.03.020

Chandrashekar R, Mainville CA, Beall MJ, O'Connor T, Eberts MD, Alleman AR, Gaunt SD, Breitschwerdt EB (2010) Performance of a commercially available in-clinic ELISA for the detection of antibodies against Anaplasma phagocytophilum, Ehrlichia canis, and Borrelia burgdorferi and Dirofilaria immitis antigen in dogs. Am J Vet Res 71:1443-1450. https://doi.org/10.2460/ajvr.71.12.1443

Che L-h et al (2019) Monitoring the course of Brucella infection with qPCR-based detection. Int J Infect Dis 89:66-71. https://doi.org/10. 1016/j.ijid.2019.09.013

Cheng J, Zhang L, Hu B, Wang Q, Wu R, Zhan F, Rong S, Zhan J (2019) Prevalence and molecular phylogenetic analysis of severe fever with thrombocytopenia syndrome virus in domestic animals and rodents in Hubei Province, China. Virol Sin 34:596-600. https://doi.org/10. 1007/s12250-019-00119-y

Cheslock MA, Embers ME (2019) Human bartonellosis: an underappreciated public health problem? Trop Med Infect Dis 4:69. https://doi. org/10.3390/tropicalmed4020069

Courtney JW, Kostelnik LM, Zeidner NS, Massung RF (2004) Multiplex real-time PCR for detection of Anaplasma phagocytophilum and Borrelia burgdorferi. J Clin Microbiol 42:3164-3168. https://doi. org/10.1128/jcm.42.7.3164-3168.2004

Cursino-Santos JR, Alhassan A, Singh M, Lobo CA (2014) Babesia: impact of cold storage on the survival and the viability of parasites in blood bags. Transfusion 54:585-591. https://doi.org/10.1111/trf. 12357

Cutler S, Vayssier-Taussat M, Estrada-Peña A, Potkonjak A, Mihalca AD, Zeller H (2019) A new Borrelia on the block: Borrelia miyamotoi - a human health risk? Eurosurveillance 24:1800170. https://doi.org/10.2807/1560-7917.ES.2019.24.18.1800170

Dantas-Torres F, Chomel BB, Otranto D (2012) Ticks and tick-borne diseases: a One Health perspective. Trends Parasitol 28:437-446. https://doi.org/10.1016/j.pt.2012.07.003

Das S, Hammond-McKibben D, Guralski D, Lobo S, Fiedler PN (2020) Development of a sensitive molecular diagnostic assay for detecting Borrelia burgdorferi DNA from blood of Lyme disease patients by digital PCR. PLoS One 15:e0235372. https://doi.org/10.1101/2020. 06.16 .154336

Dessau R et al (2014) The lymphocyte transformation test for the diagnosis of Lyme borreliosis has currently not been shown to be clinically useful. Clin Microbiol Infect 20:O786-O787. https://doi.org/ 10.1111/1469-0691.12583

Diniz PPVP, Schulz BS, Hartmann K, Breitschwerdt EB (2011) "Candidatus Neoehrlichia mikurensis" infection in a dog from Germany. J Clin Microbiol 49:2059-2062. https://doi.org/10.1128/ JCM.02327-10

Divers TJ (2013) Equine Lyme disease. J Equine Vet Sci 33:488-492. https://doi.org/10.1016/j.jevs.2013.03.187

Dobler G, Pfeffer M (2012) Spotted fever rickettsiae and rickettsioses in Germany. In: Arthropods as vectors of emerging diseases. Parasitology research monographs 3. Springer, Berlin Heidelberg, pp 361-376. https://doi.org/10.1007/978-3-642-28842-5 15

Dobler G, Gniel D, Petermann R, Pfeffer M (2012) Epidemiology and distribution of tick-borne encephalitis. Wien Med Wochenschr 162: 230-238. https://doi.org/10.1007/s10354-012-0100-5

Dugat T, Lagree AC, Maillard R, Boulouis HJ, Haddad N (2015) Opening the black box of Anaplasma phagocytophilum diversity: current situation and future perspectives. Front Cell Infect Microbiol 5:61. https://doi.org/10.3389/fcimb.2015.00061

Dumler JS, Madigan JE, Pusterla N, Bakken JS (2007) Ehrlichioses in humans: epidemiology, clinical presentation, diagnosis, and treatment. Clin Infect Dis 45:S45-S51. https://doi.org/10.1086/518146

Duron O, Sidi-Boumedine K, Rousset E, Moutailler S, Jourdain E (2015) The importance of ticks in $\mathrm{Q}$ fever transmission: what has (and has not) been demonstrated? Trends Parasitol 31:536-552. https://doi. org/10.1016/j.pt.2015.06.014

Ebel GD (2010) Update on Powassan virus: emergence of a North American tick-borne flavivirus. Annu Rev Entomol 55:95-110. https://doi.org/10.1146/annurev-ento-112408-085446

Eldin C, Jaulhac B, Mediannikov O, Arzouni J-P, Raoult D (2019) Values of diagnostic tests for the various species of spirochetes. Med Mal Infect 49:102-111. https://doi.org/10.1016/j.medmal. 2019.01.009

Eshoo MW, Crowder CD, Li H, Matthews HE, Meng S, Sefers SE, Sampath R, Stratton CW, Blyn LB, Ecker DJ, Tang YW (2010) Detection and identification of Ehrlichia species in blood by use of PCR and electrospray ionization mass spectrometry. J Clin Microbiol 48:472-478. https://doi.org/10.1128/jcm.01669-09

Eshoo MW, Crowder CC, Rebman AW, Rounds MA, Matthews HE, Picuri JM, Soloski MJ, Ecker DJ, Schutzer SE, Aucott JN (2012) Direct molecular detection and genotyping of Borrelia burgdorferi from whole blood of patients with early Lyme disease. PLoS One 7: e36825. https://doi.org/10.1371/journal.pone.0036825

Faggion S, Salvador AR, Jacobino KL, Bortolotto LFB, Lopes MB, Silva M, Santos EV, Fachin AL, França SC, Marins M (2013) Loopmediated isothermal amplification assay for the detection of Ehrlichia canis DNA in blood samples from dogs. Arch Med Vet 45:197-201. https://doi.org/10.4067/S0301-732X2013000200012

Fares M, Cochet-Bernoin M, Gonzalez G, Montero-Menei CN, Blanchet O, Benchoua A, Boissart C, Lecollinet S, Richardson J, Haddad N, Coulpier M (2020) Pathological modeling of TBEV infection reveals differential innate immune responses in human neurons and astrocytes that correlate with their susceptibility to infection. J Neuroinflammation 17:76. https://doi.org/10.1186/s12974-02001756-X

Gerber B, Eichenberger S, Haug K, Wittenbrink MM (2009) The dilemma with Lyme borreliosis in the dog with particular consideration of "Lyme nephritis". Schweiz Arch Tierheilkd 151:479-483. https:// doi.org/10.1024/0036-7281.151.10.479

Gerritzen A, Brandt S (2012) Serodiagnosis of Lyme borreliosis with bead based immunoassays using multiplex technology. Methods 56:477-483. https://doi.org/10.1016/j.ymeth.2012.02.007 
Gilbert L (2016) Louping ill virus in the UK: a review of the hosts, transmission and ecological consequences of control. Exp Appl Acarol 68:363-374. https://doi.org/10.1007/s10493-015-9952-x

Girl P, Bestehorn-Willmann M, Zange S, Borde JP, Dobler G, von Buttlar $\mathrm{H}$ (2020) Tick-borne encephalitis virus nonstructural protein $1 \mathrm{IgG}$ enzyme-linked immunosorbent assay for differentiating infection versus vaccination antibody responses. J Clin Microbiol 58: e01783-e01719. https://doi.org/10.1128/jcm.01783-19

Gray J, Zintl A, Hildebrandt A, Hunfeld KP, Weiss L (2010) Zoonotic babesiosis: overview of the disease and novel aspects of pathogen identity. Ticks Tick Borne Dis 1:3-10. https://doi.org/10.1016/j. ttbdis.2009.11.003

Gray A, Capewell P, Loney C, Katzer F, Shiels BR, Weir W (2019a) Sheep as host species for zoonotic Babesia venatorum, United Kingdom. Emerg Infect Dis 25:2257-2260. https://doi.org/10. 3201/eid2512.190459

Gray JS, Estrada-Peña A, Zintl A (2019b) Vectors of babesiosis. Annu Rev Entomol 64:149-165. https://doi.org/10.1146/annurev-ento011118-111932

Guido M, Tumolo MR, De Donno A, Verri T, Serio F, Bagordo F, Zizza A (2016) In vitro diagnosis of sepsis: a review. Pathol Lab Med Int 8:1-14. https://doi.org/10.2147/PLMI.S49800

Häselbarth K, Tenter AM, Brade V, Krieger G, Hunfeld K-P (2007) First case of human babesiosis in Germany - clinical presentation and molecular characterisation of the pathogen. Int J Med Microbiol 297:197-204. https://doi.org/10.1016/j.ijmm.2007.01.002

Hayasaka D, Aoki K, Morita K (2013) Development of simple and rapid assay to detect viral RNA of tick-borne encephalitis virus by reverse transcription-loop-mediated isothermal amplification. Virol J 10:68. https://doi.org/10.1186/1743-422X-10-68

Hildebrandt A, Hunfeld KP, Baier M, Krumbholz A, Sachse S, Lorenzen T, Kiehntopf M, Fricke HJ, Straube E (2007) First confirmed autochthonous case of human Babesia microti infection in Europe. Eur J Clin Microbiol Infect Dis 26:595-601. https://doi.org/10.1007/ s10096-007-0333-1

Hildebrandt A, Tenter AM, Straube E, Hunfeld K-P (2008) Human babesiosis in Germany: just overlooked or truly new? Int J Med Microbiol 298:336-346. https://doi.org/10.1016/j.ijmm.2007.11.001

Imhoff M, Hagedorn P, Schulze Y, Hellenbrand W, Pfeffer M, Niedrig M (2015) Review: Sentinels of tick-borne encephalitis risk. Ticks Tickborne Dis 6:592-600. https://doi.org/10.1016/j.ttbdis.2015.05.001

IZS "G. Caporale" (2009) Scientific review on crimean-congo hemorrhagic fever. EFSA Suppor Publicat 6:19E. https://doi.org/10. 2903/sp.efsa.2009.EN-19

Jaarsma RI, Sprong H, Takumi K, Kazimirova M, Silaghi C, Mysterud A, Rudolf I, Beck R, Földvári G, Tomassone L, Groenevelt M, Everts RR, Rijks JM, Ecke F, Hörnfeldt B, Modrý D, Majerová K, Votýpka J, Estrada-Peña A (2019) Anaplasma phagocytophilum evolves in geographical and biotic niches of vertebrates and ticks. Parasit Vectors 12:328. https://doi.org/10.1186/s13071-019-3583-8

Jahfari S, Sprong H (2016) Emerging tick-borne pathogens: ticking on Pandora's box. In: MAH B, Van Wieren SE, Takken W, Sprong H (eds) Ecology and prevention of Lyme borreliosis. Ecology and control of vector-borne diseases, vol 4. Wageningen Academic Publishers, Wageningen, pp 127-147. https://doi.org/10.3920/97890-8686-838-4 9

Jin C, Roen DR, Lehmann PV, Kellermann GH (2013) An enhanced ELISPOT assay for sensitive detection of antigen-specific $\mathrm{T}$ cell responses to Borrelia burgdorferi. Cells 2:607-620. https://doi. org/10.3390/cells2030607

Kalyuzhny E (2005) Handbook of ELISPOT. Methods and protocols. Methods in molecular biology, vol 302. Humana Press Inc., Totowa, pp 1-323

Karpathy SE, Allerdice MEJ, Sheth M, Dasch GA, Levin ML (2016) Cofeeding transmission of the Ehrlichia muris-like agent to mice (Mus musculus). Vector Borne Zoonotic Dis 16:145-150. https://doi.org/ 10.1089/vbz.2015.1878

Keenan KP, Buhles WC, Huxsoll DL, Williams RG, Hildebrandt PK (1977) Studies on the pathogenesis of Rickettsia rickettsii in the dog: clinical and clinicopathologic changes of experimental infection. Am J Vet Res 38:851-856 PMID: 879582

Keirans J, Needham G, Oliver J Jr (1999) The Ixodes ricinus complex worldwide: diagnosis of the species in the complex, hosts and distribution. Acarology IX Proceedings 2:341-347

Kelly PJ, Mason PR (1991) Transmission of a spotted fever group rickettsia by Amblyomma hebraeum (Acari: Ixodidae). J Med Entomol 28:598-600. https://doi.org/10.1093/jmedent/28.5.598

Koch-Institut R (2020) FSME: Risikogebiete in Deutschland (Stand: Januar 2020). Epidemiol Bull 2020:3-19

Kohn B, Galke D, Beelitz P, Pfister K (2008) Clinical features of canine granulocytic anaplasmosis in 18 naturally infected dogs. J Vet Intern Med 22:1289-1295. https://doi.org/10.1111/j.1939-1676.2008.0180.x

Korber F, Zeller I, Grünstäudl M, Willinger B, Apfalter P, Hirschl AM, Makristathis A (2017) SeptiFast versus blood culture in clinical routine - a report on 3 years experience. Wien Klin Wochenschr 129:427-434. https://doi.org/10.1007/s00508-017-1181-3

Körner S, Makert GR, Mertens-Scholz K, Henning K, Pfeffer M, Starke A, Nijhof AM, Ulbert S (2020) Uptake and fecal excretion of Coxiella burnetii by Lxodes ricinus and Dermacentor marginatus ticks. Parasit Vectors 13:75. https://doi.org/10.1186/s13071-020-3956-Z

Kuleš J, Potocnakova L, Bhide K, Tomassone L, Fuehrer HP, Horvatić A, Galan A, Guillemin N, Nižić P, Mrljak V, Bhide M (2017) The challenges and advances in diagnosis of vector-borne diseases: where do we stand? Vector Borne Zoonotic Dis 17:285-296. https://doi.org/10.1089/vbz.2016.2074

Lagler H, Harrison N, Kussmann M, Obermüller M, Burgmann H, Makristathis A, Ramharter M (2017) Direct detection of Anaplasma phagocytophilum by polymerase chain reaction followed by electrospray ionization mass spectrometry from human blood. Int J Infect Dis 60:61-63. https://doi.org/10.1016/j.ijid.2017.05.006

Landry ML (2016) Immunoglobulin M for acute infection: true or false? Clin Vaccine Immunol 23:540-545. https://doi.org/10.1128/CVI. 00211-16

Ličková M, Fumačová Havlíková S, Sláviková M, Slovák M, Drexler JF, Klempa B (2020) Dermacentor reticulatus is a vector of tick-borne encephalitis virus. Ticks Tick Borne Dis 11:101414. https://doi.org/ 10.1016/j.ttbdis.2020.101414

Littman MP, Gerber B, Goldstein RE, Labato MA, Lappin MR, Moore GE (2018) ACVIM consensus update on Lyme borreliosis in dogs and cats. J Vet Intern Med 32:887-903. https://doi.org/10.1111/ jvim. 15085

Liu J, Drexel J, Andrews B, Eberts M, Breitschwerdt E, Chandrashekar R (2018) Comparative evaluation of 2 in-clinic assays for vector-borne disease testing in dogs. Top Companion Anim Med 33:114-118. https://doi.org/10.1053/j.tcam.2018.09.003

Lohr B, Müller I, Mai M, Norris DE, Schöffski O, Hunfeld KP (2015) Epidemiology and cost of hospital care for Lyme borreliosis in Germany: lessons from a health care utilization database analysis. Ticks Tick Borne Dis 6:56-62. https://doi.org/10.1016/j.ttbdis. 2014.09.004

Magni R, Luchini A, Liotta L, Molestina RE (2020) Proteomic analysis reveals pathogen-derived biomarkers of acute babesiosis in erythrocytes, plasma, and urine of infected hamsters. Parasitol Res 119: 2227-2235. https://doi.org/10.1007/s00436-020-06712-5

Mansfield KL, Jizhou L, Phipps LP, Johnson N (2017) Emerging tickborne viruses in the twenty-first century. Front Cell Infect Microbiol 7:298. https://doi.org/10.3389/fcimb.2017.00298

Martinot M, Zadeh MM, Hansmann Y, Grawey I, Christmann D, Aguillon S, Jouglin M, Chauvin A, de Briel D (2011) Babesiosis in immunocompetent patients, Europe. Emerg Infect Dis 17:114116. https://doi.org/10.3201/eid1701.100737 
Mavin S, Evans R, Cornulier T, Bowman AS (2018) The development of an IgG avidity Western blot with potential to differentiate patients with active Lyme borreliosis from those with past infection. J Microbiol Methods 146:71-76. https://doi.org/10.1016/j.mimet. 2018.02.002

Molloy PJ, Weeks KE, Todd B, Wormser GP (2017) Seroreactivity to the C6 peptide in Borrelia miyamotoi infections occurring in the Northeastern United States. Clin Infect Dis 66:1407-1410. https:// doi.org/10.1093/cid/cix1023

Moraes-Filho J, Krawczak FS, Costa FB, Soares JF, Labruna MB (2015) Comparative evaluation of the vector competence of four South American populations of the Rhipicephalus sanguineus group for the bacterium Ehrlichia canis, the agent of canine monocytic ehrlichiosis. PLoS One 10:e139386. https://doi.org/10.1371/journal. pone. 0139386

Neumann-Cip A-C, Fingerle V, Margos G, Straubinger RK, Overzier E, Ulrich S, Wieser A (2020) A novel rapid sample preparation method for MALDI-TOF MS permits Borrelia burgdorferi sensu lato species and isolate differentiation. Front Microbiol 11:690. https://doi. org $/ 10.3389 /$ fmicb. 2020.00690

Nieder M, Silaghi C, Hamel D, Pfister K, Schmaschke R, Pfeffer M (2012) Tick-borne fever caused by Anaplasma phagocytophilum in Germany: first laboratory confirmed case in a dairy cattle herd. Tierarztl Prax Ausg G Grosstiere Nutztiere 40:101-106 PMID: 22526723

Ord RL, Lobo CA (2015) Human babesiosis: pathogens, prevalence, diagnosis, and treatment. Curr Clin Microbiol Rep 2:173-181. https://doi.org/10.1007/s40588-015-0025-Z

Ozanic M, Marecic V, Abu Kwaik Y, Santic M (2015) The divergent intracellular lifestyle of Francisella tularensis in evolutionarily distinct host cells. PLoS Pathog 11:e1005208. https://doi.org/10.1371/ journal.ppat.1005208

Özenci V, Patel R, Ullberg M, Strålin K (2017) Demise of polymerase chain reaction/electrospray ionization-mass spectrometry as an infectious diseases diagnostic tool. Clin Infect Dis 66:452-455. https://doi.org/10.1093/cid/cix743

Pantchev N, Pluta S, Huisinga E, Nather S, Scheufelen M, Vrhovec MG, Schweinitz A, Hampel H, Straubinger RK (2015) Tick-borne diseases (borreliosis, anaplasmosis, babesiosis) in German and Austrian dogs: status quo and review of distribution, transmission, clinical findings, diagnostics and prophylaxis. Parasitol Res 114:19 54. https://doi.org/10.1007/s00436-015-4513-0

Parola P, Paddock CD, Socolovschi C, Labruna MB, Mediannikov O, Kernif T, Abdad MY, Stenos J, Bitam I, Fournier PE, Raoult D (2013) Update on tick-borne rickettsioses around the world: a geographic approach. Clin Microbiol Rev 26:657-702. https://doi.org/ 10.1128/CMR.00032-13

Pfeffer M, Dobler G (2011) Tick-borne encephalitis virus in dogs - is this an issue? Parasit Vectors 4:59. https://doi.org/10.1186/1756-3305-4-59

Platonov AE, Karan LS, Kolyasnikova NM, Makhneva NA, Toporkova MG, Maleev VV, Fish D, Krause PJ (2011) Humans infected with relapsing fever spirochete Borrelia miyamotoi, Russia. Emerg Infect Dis 17:1816-1823. https://doi.org/10.3201/eid1710.101474

Portillo A, de Sousa R, Santibáñez S, Duarte A, Edouard S, Fonseca IP, Marques C, Novakova M, Palomar AM, Santos M, Silaghi C, Tomassone L, Zúquete S, Oteo JA (2017) Guidelines for the Detection of Rickettsia spp. Vector Borne Zoonotic Dis 17:23-32. https://doi.org/10.1089/vbz.2016.1966

Pritt BS, Allerdice MEJ, Sloan LM, Paddock CD, Munderloh UG, Rikihisa Y, Tajima T, Paskewitz SM, Neitzel DF, Hoang Johnson DK, Schiffman E, Davis JP, Goldsmith CS, Nelson CM, Karpathy SE (2017) Proposal to reclassify Ehrlichia muris as Ehrlichia muris subsp. muris subsp. nov. and description of Ehrlichia muris subsp. eauclairensis subsp. nov., a newly recognized tick-borne pathogen of humans. Int J Syst Evol Microbiol 67:2121-2126. https://doi.org/ 10.1099/ijsem.0.001896
Raffetin A, Saunier A, Bouiller K, Caraux-Paz P, Eldin C, Gallien S, Jouenne R, Belkacem A, Salomon J, Patey O, Talagrand-Reboul E, Jaulhac B, Grillon A (2020) Unconventional diagnostic tests for Lyme borreliosis: a systematic review. Clin Microbiol Infect 26:5159. https://doi.org/10.1016/j.cmi.2019.06.033

Rar V, Golovljova I (2011) Anaplasma, Ehrlichia, and "Candidatus Neoehrlichia" bacteria: pathogenicity, biodiversity, and molecular genetic characteristics, a review. Infect Genet Evol 11:1842-1861. https://doi.org/10.1016/j.meegid.2011.09.019

Reiner B, Fischer A (1998) European tick-borne meningoencephalitis in dogs in Germany: two case reports. Kleintierpraxis 43:255-268

Reller ME, Dumler JS (2018) Development and clinical validation of a multiplex real-time quantitative PCR assay for human infection by Anaplasma phagocytophilum and Ehrlichia chaffeensis. Trop Med Infect Dis 3:14. https://doi.org/10.3390/tropicalmed3010014

Reusken C, Boonstra M, Rugebregt S, Scherbeijn S, Chandler F, AvšičŽupanc T, Vapalahti O, Koopmans M, GeurtsvanKessel CH (2019) An evaluation of serological methods to diagnose tick-borne encephalitis from serum and cerebrospinal fluid. J Clin Virol 120: 78-83. https://doi.org/10.1016/j.jcv.2019.09.009

Rizzoli A, Silaghi C, Obiegala A, Rudolf I, Hubálek Z, Földvári G, Plantard O, Vayssier-Taussat M, Bonnet S, Špitalská E, Kazimírová M (2014) Ixodes ricinus and its transmitted pathogens in urban and peri-urban areas in Europe: new hazards and relevance for public health. Front Public Health 2:251. https://doi.org/10.3389/ fpubh.2014.00251

Rudenko N, Golovchenko M, Grubhoffer L, Oliver JH (2011) Updates on Borrelia burgdorferi sensu lato complex with respect to public health. Ticks Tick Borne Dis 2:123-128. https://doi.org/10.1016/j. ttbdis.2011.04.002

Růžek D, Yakimenko VV, Karan LS, Tkachev SE (2010) Omsk haemorrhagic fever. Lancet 376:2104-2113. https://doi.org/10. 1016/s0140-6736(10)61120-8

Saenger K, Danner K, Maurer M, Bago Z (2013) Tick-borne encephalitis (TBE) in a dog. Praktische Tierarzt 94:392-396

Sahni SK, Rydkina E (2009) Host-cell interactions with pathogenic Rickettsia species. Future Microbiol 4:323-339. https://doi.org/10. 2217/fmb.09.6

Sanchez E, Vannier E, Wormser GP, Hu LT (2016) Diagnosis, treatment, and prevention of Lyme disease, human granulocytic anaplasmosis, and babesiosis: a review. JAMA 315:1767-1777. https://doi.org/10. 1001/jama.2016.2884

Sawatsky B, McAuley AJ, Holbrook MR, Bente DA (2014) Comparative pathogenesis of Alkhumra hemorrhagic fever and Kyasanur forest disease viruses in a mouse model. PLoS Negl Trop Dis 8:e2934 e2934. https://doi.org/10.1371/journal.pntd.0002934

Schotthoefer AM, Meece JK, Ivacic LC, Bertz PD, Zhang K, Weiler T, Uphoff TS, Fritsche TR (2013) Comparison of a real-time PCR Method with serology and blood smear analysis for diagnosis of human anaplasmosis: importance of infection time course for optimal test utilization. J Clin Microbiol 51:2147-2153. https://doi.org/ 10.1128/jcm.00347-13

Schutzer SE, Body BA, Boyle J, Branson BM, Dattwyler RJ, Fikrig E, Gerald NJ, Gomes-Solecki M, Kintrup M, Ledizet M, Levin AE, Lewinski M, Liotta LA, Marques A, Mead PS, Mongodin EF, Pillai S, Rao P, Robinson WH, Roth KM, Schriefer ME, Slezak T, Snyder JL, Steere AC, Witkowski J, Wong SJ, Branda JA (2018) Direct diagnostic tests for Lyme disease. Clin Infect Dis 68:1052-1057. https://doi.org/10.1093/cid/ciy614

Seriburi V, Ndukwe N, Chang Z, Cox ME, Wormser GP (2012) High frequency of false positive IgM immunoblots for Borrelia burgdorferi in clinical practice. Clin Microbiol Infect 18:12361240. https://doi.org/10.1111/j.1469-0691.2011.03749.x

Shah SZ, Jabbar B, Ahmed N, Rehman A, Nasir H, Nadeem S, Jabbar I, Rahman Z, Azam S (2018) Epidemiology, pathogenesis, and control of a tick-borne disease- Kyasanur forest disease: current status and 
future directions. Front Cell Infect Microbiol 8:149. https://doi.org/ 10.3389/fcimb.2018.00149

Sheahan BJ, Moore M, Atkins GJ (2002) The pathogenicity of Louping ill virus for mice and lambs. J Comp Pathol 126:137-146. https:// doi.org/10.1053/jcpa.2001.0533

Silaghi C, Liebisch G, Pfister K (2011) Genetic variants of Anaplasma phagocytophilum from 14 equine granulocytic anaplasmosis cases. Parasit Vectors 4:161. https://doi.org/10.1186/1756-3305-4-161

Singh MD, Singh H, Singh NK, Singh NK, Kashyap N, Sood NK, Rath SS (2019) Development of loop-mediated isothermal amplification (LAMP) assay for detection of Hepatozoon canis infection in dogs. Ticks Tick Borne Dis 10:371-376. https://doi.org/10.1016/j.ttbdis. 2018.11.016

Smit PW, Kurkela S, Kuusi M, Vapalahti O (2015) Evaluation of two commercially available rapid diagnostic tests for Lyme borreliosis. Eur J Clin Microbiol Infect Dis 34:109-113. https://doi.org/10. 1007/s10096-014-2217-5

Snellgrove AN, Krapiunaya I, Ford SL, Stanley HM, Wickson AG, Hartzer KL, Levin ML (2020) Vector competence of Rhipicephalus sanguineus sensu stricto for Anaplasma platys. Ticks Tick Borne Dis 11:101517. https://doi.org/10.1016/j.ttbdis. 2020.101517

Solano-Gallego L, Kidd L, Trotta M, Di Marco M, Caldin M, Furlanello T, Breitschwerdt E (2006) Febrile illness associated with Rickettsia conorii infection in dogs from Sicily. Emerg Infect Dis 12:19851988. https://doi.org/10.3201/eid1212.060326

Solano-Gallego L, Sainz Á, Roura X, Estrada-Peña A, Miró G (2016) A review of canine babesiosis: the European perspective. Parasit Vectors 9:336. https://doi.org/10.1186/s13071-016-1596-0

Sonenshine DE (2018) Range expansion of tick disease vectors in North America: implications for spread of tick-borne disease. Int J Environ Res Public Health 15:478. https://doi.org/10.3390/ijerph15030478

Springer A, Höltershinken M, Lienhart F, Ermel S, Rehage J, Hülskötter K, Lehmbecker A, Wohlsein P, Barutzki D, Gietl C, Baumgärtner W, Hoedemaker M, Strube C (2020) Emergence and epidemiology of bovine babesiosis due to Babesia divergens on a northern German beef production farm. Front Vet Sci 7:649. https://doi.org/10.3389/ fvets.2020.00649

Suzuki T, Sato Y, Sano K, Arashiro T, Katano H, Nakajima N, Shimojima M, Kataoka M, Takahashi K, Wada Y, Morikawa S, Fukushi S, Yoshikawa T, Saijo M, Hasegawa H (2020) Severe fever with thrombocytopenia syndrome virus targets B cells in lethal human infections. J Clin Invest 130:799-812. https://doi.org/10.1172/ JCI129171

Talagrand-Reboul E, Boyer PH, Bergström S, Vial L, Boulanger N (2018) Relapsing fevers: neglected tick-borne diseases. Front Cell Infect Microbiol 8:98. https://doi.org/10.3389/fcimb.2018.00098

Tambo E, El-Dessouky AG (2018) Defeating re-emerging Alkhurma hemorrhagic fever virus outbreak in Saudi Arabia and worldwide. PLoS Negl Trop Dis 12:e006707. https://doi.org/10.1371/journal. pntd.0006707

Telford SR III, Goethert HK (2020) Ecology of Francisella tularensis. Annu Rev Entomol 65:351-372. https://doi.org/10.1146/annurevento-011019-025134

Varela-Stokes AS (2007) Transmission of bacterial agents from lone star ticks to white-tailed deer. J Med Entomol 44:478-483. https://doi. org $/ 10.1093 /$ jmedent $/ 44.3 .478$

Vilibic-Cavlek T, Barbic L, Stevanovic V, Petrovic G, MlinaricGalinovic G (2016) IgG avidity: an important serologic marker for the diagnosis of tick-borne encephalitis virus infection. Pol J Microbiol 65:119-121. https://doi.org/10.5604/17331331.1197285

von Loewenich FD, Geißdörfer W, Disqué C, Matten J, Schett G, Sakka SG, Bogdan C (2010) Detection of "Candidatus Neoehrlichia mikurensis" in two patients with severe febrile illnesses: evidence for a European sequence variant. J Clin Microbiol 48:2630-2635. https://doi.org/10.1128/jcm.00588-10

Voth DE, Heinzen RA (2007) Lounging in a lysosome: the intracellular lifestyle of Coxiella burnetii. Cell Microbiol 9:829-840. https://doi. org/10.1111/j.1462-5822.2007.00901.x

Výrosteková V (1994) Transstadial transmission of Francisella tularensis by Ixodes ricinus ticks infected during the nymphal stage. Epidemiol Mikrobiol Imunol 43:166-170 PMID: 7850217

Waddell LA, Greig J, Mascarenhas M, Harding S, Lindsay R, Ogden N (2016) The accuracy of diagnostic tests for Lyme disease in humans, a systematic review and meta-analysis of North American research. PLoS One 11:e0168613. https://doi.org/10.1371/journal.pone. 0168613

Wagner B, Freer H, Rollins A, Erb HN (2011a) A fluorescent bead-based multiplex assay for the simultaneous detection of antibodies to B. burgdorferi outer surface proteins in canine serum. Vet Immunol Immunopathol 140:190-198. https://doi.org/10.1016/j. vetimm.2010.12.003

Wagner B, Freer H, Rollins A, Erb HN, Lu Z, Gröhn Y (2011b) Development of a multiplex assay for the detection of antibodies to Borrelia burgdorferi in horses and its validation using Bayesian and conventional statistical methods. Vet Immunol Immunopathol 144:374-381. https://doi.org/10.1016/j.vetimm.2011.08.005

Waldvogel A, Matile H, Wegmann C, Wyler R, Kunz C (1981) Tickborne encephalitis in the horse. Schweiz Arch Tierheilkd 123:227233. https://doi.org/10.5169/seals-591597

Wang J, Zhang Y, Wang X, Cui Y, Yan Y, Wang R, Jian F, Zhang L, Ning C (2017) A loop-mediated isothermal amplification assay targeting 16S rRNA gene for rapid detection of Anaplasma phagocytophilum infection in sheep and goats. J Parasitol 103: 187-192. https://doi.org/10.1645/16-158

Wass L, Grankvist A, Bell-Sakyi L, Bergström M, Ulfhammer E, Lingblom C, Wennerås C (2019) Cultivation of the causative agent of human neoehrlichiosis from clinical isolates identifies vascular endothelium as a target of infection. Emerg Microbes Infect 8:413 425. https://doi.org/10.1080/22221751.2019.1584017

Welinder-Olsson C, Kjellin E, Vaht K, Jacobsson S, Wennerås C (2010) First case of human "Candidatus Neoehrlichia mikurensis" infection in a febrile patient with chronic lymphocytic leukemia. J Clin Microbiol 48:1956-1959. https://doi.org/10.1128/jcm.02423-09

Wennerås C (2015) Infections with the tick-borne bacterium Candidatus Neoehrlichia mikurensis. Clin Microbiol Infect 21:621-630. https:// doi.org/10.1016/j.cmi.2015.02.030

Xu G, Fang QQ, Keirans JE, Durden LA (2003) Molecular phylogenetic analyses indicate that the Ixodes ricinus complex is a paraphyletic group. J Parasitol 89:452-457. https://doi.org/10.1645/00223395(2003)089[0452:mpaitt]2.0.co;2

Yabsley MJ (2010) Natural history of Ehrlichia chaffeensis: Vertebrate hosts and tick vectors from the United States and evidence for endemic transmission in other countries. Vet Parasitol 167:136-148. https://doi.org/10.1016/j.vetpar.2009.09.015

Yukl S, Wong JK (2016) Colorado tick fever and other arthropod borne Reoviridae. In: Richman DD, Whitley RJ, Hayden FG (eds) Clinical virology, 4th edn. ASM Press, Washington, D.C., pp 841-852. https://doi.org/10.1128/9781555819439.ch35

Zintl A, Mulcahy G, Skerrett HE, Taylor SM, Gray JS (2003) Babesia divergens, a bovine blood parasite of veterinary and zoonotic importance. Clin Microbiol Rev 16:622-636. https://doi.org/10.1128/ cmr.16.4.622-636.2003

Publisher's note Springer Nature remains neutral with regard to jurisdictional claims in published maps and institutional affiliations. 